\title{
PERFIL PROFISSIONAL E DISTRIBUIÇÃO REGIONAL DOS SENADORES BRASILEIROS EM DOIS SÉCULOS DE HISTÓRIA
}

\section{Pedro Neiva Maurício Izumi}

\section{Introdução}

Esse estudo procura mapear diacronicamente o repertório biográfico de todos os senadores brasileiros, desde a primeira legislatura em 1826 até a última, que se iniciou em 2010. Especificamente, aborda suas profissões/ocupaçōes, ${ }^{1}$ procurando avaliar possíveis relações com as mudanças históricas na composição política e na estrutura social e econômica do país.

Uma pesquisa sobre o perfil dos senadores nos parece oportuna, por diversos motivos. O primeiro é a carência de estudos a esse respeito. Existem trabalhos interessantes sobre elites políticas no país que avaliaram a composição profissional/ocupacional sob uma perspectiva histórica (Carvalho, 2010; Coelho, 1999; Rodrigues, 2002), mas nenhum de-

Artigo recebido em 07/11/2012

Aprovado em 11/12/2013 les abrangeu um período de tempo tão longo; tampouco estudou o Senado com exclusividade.

O segundo motivo decorre do papel de destaque que o Senado exerceu na história política brasileira, especialmente durante o Império, quando se tornou a câmara mais forte e prestigiada do Legislativo (Leite, 1978). Nas palavras de Faoro (1958, p. 173), "o Senado foi pela origem uma instituição da Coroa, ligada aos seus interesses e participando de sua política [...] era o agente do estamento burocrático. Foi um órgão do qual se servia o Poder Moderador para dominar a Câmara e o Ministério". Seus membros tinham relaçôes estreitas com o monarca e eram por ele selecionados a partir de listas tríplices indicadas pelas províncias.

De acordo com Leite (1978, p. 44), “o cargo de senador representava o coroamento de uma carreira brilhante. Para galgá-lo, fazia-se necessário experiência [...]. Era preciso que já tivesse ultrapassado importantes degraus na arte da política, tivesse uma 
aprendizagem prática a partir da ocupação de cargos como deputado, ministro, diplomata, presidente de província e conselheiro de Estado". ${ }^{2}$ Segundo a autora, nada menos que $56 \%$ e $37 \%$ dos senadores, respectivamente, haviam exercido esses dois últimos cargos nas duas décadas finais do Império.

Segundo Wanderley Pinho, "o Senado representava, para um político do Império, tudo. A vitaliciedade era uma garantia perpétua contra o olvido, o obscurecimento, a derrota, o fracasso [...] não dependia o senador, até a morte, das circunstâncias favoráveis ou adversas para ter uma situação, uma tribuna" (1937, p. 500). Além disso, contavam com mandato vitalício, recebiam remuneração equivalente a uma vez e meia ao que era destinado aos deputados e não perdiam o mandato quando participavam do Conselho de Estado - o principal centro decisório da época -, ao contrário do que acontecia com esses últimos.

Durante o período republicano, muitos senadores exerceram cargos superiores, tais como governador de estado, ministro e até presidente e vice-presidente da República. Segundo Neiva (2011), quase metade deles ocupou tais cargos no período posterior à Constituição de 1988, contra apenas 20\% dos deputados. Como uma evidência de "ambição progressiva”, o autor afirma que mais de $50 \%$ dos senadores que tomaram posse no período de 1987 a 2000 ocuparam anteriormente o cargo de deputado, enquanto o inverso só aconteceu em 1,5\% dos casos. Nos dois períodos (Império e República), passaram pelo Senado nomes ilustres da história do Brasil, como: José Bonifácio, Visconde de Itaboraí, Visconde do Uruguai, Visconde do Rio Branco, Princesa Isabel, Duque de Caxias, Ruy Barbosa, Campos Salles, Barão do Rio Branco, Floriano Peixoto, Luís Carlos Prestes, Assis Chateaubriand, Getúlio Vargas, Tancredo Neves, Juscelino Kubitschek, Fernando Henrique Cardoso, entre outros.

Outra importante justificativa para o estudo dos senadores em uma perspectiva longitudinal é que eles fazem parte de uma casa legislativa que se enquadra muito bem no conceito de protean ${ }^{3}$ que Tsebelis e Money (1997) usaram para descrever as câmaras altas, isto é, contam com amplos poderes, adaptam-se facilmente a diferentes contextos e situações e servem a diferentes propósitos.
Tal capacidade "adaptadora" esteve presente em diversos momentos na história política do país e serviu para atender os interesses das forças dominantes no momento. No período monárquico, a escolha dos senadores permitia ao imperador agradar e contemplar seus protegidos e aliados políticos. Durante o regime militar iniciado em 1964, o melhor exemplo de moldagem ao contexto foi dado pelo "Pacote de Abril", que proporcionou poderes excepcionais ao presidente da República para indicar um terço dos senadores, os quais ficaram conhecidos como "biônicos". ${ }^{4}$ No período de retomada democrática, cabe citar a transformação dos antigos territórios em estados, o que aumentou substancialmente a participação de representantes de regiōes "atrasadas" e politicamente conservadoras no Senado, em detrimento das regiōes mais "avançadas" do país.

Essa perspectiva "camaleônica" do Senado pode tornar-se especialmente importante no contexto oscilante de centralização e descentralização da organização federativa brasileira e do contexto de transição negociada, e sem rupturas, entre as elites do regime autoritário e do regime democrático que se iniciou no final dos anos de 1980. Muitos de seus representantes, alguns deles senadores, permaneceram fortes em ambos os regimes. A nossa sugestão é que a circulação de elites no período de transições democráticas foi capaz de acomodar as mudanças na sociedade, mesclando elementos novos e velhos, sem que houvesse rupturas revolucionárias (Pareto, 1966).

É importante esclarecer que tratamos de apenas um dos atributos dos senadores: a sua categoria ocupacional/profissional. Estamos cientes que ela, por si só, não é informação suficiente para sugerir respostas taxativas ou para se tirar conclusões mais amplas sobre os conflitos sociais e políticos presentes na sociedade. No entanto, ao se tratar de um período tão extenso, ela pode sinalizar como os senadores são socializados e o tipo de grupo com o qual se identificam - se trabalhadores ou empresários, por exemplo. Afinal, conforme afirmam Lareau e Conley (2008), a ocupação do indivíduo é um dos maiores preditores do seu comportamento, das suas predisposiçôes e de suas atitudes políticas. 
$\mathrm{Na}$ seção que se segue, fazemos uma avaliação das profissões mais encontradas em diversos parlamentos no mundo. Na terceira seção, apresentamos nossos dados e alguns problemas metodológicos. $\mathrm{Na}$ quarta, analisamos a evolução das categorias profissionais mais importantes. Em seguida, verificamos o impacto da mudança das regras de seleção dos senadores sobre a sua distribuição estadual, tomando como exemplo três profissões fundamentais: empresários rurais, empresários urbanos e profissionais do direito. Por fim, na última seção, apresentamos algumas considerações finais.

\section{Profissóes de parlamentares ao redor do mundo}

Os parlamentares costumam exercer profissões de maior prestígio social do que a maioria da população. Em grande parte, isso é explicado pelo fato de que eles contam com nível educacional mais elevado do que a média da população (Matthews, 1985). Na Alemanha, na Dinamarca, no Reino Unido, na Itália, na Noruega, em Portugal e nos Países Baixos quase todos contavam com curso superior (Gaxie e Godmer, 2007). Na África, em uma amostra de onze países, Mattes e Mozaffar (2011) verificaram que $58 \%$ dos parlamentares, em média, possuíam curso superior completo, em contraste com a grande parcela analfabeta da população. $\mathrm{Na}$ Croácia, os números chegaram a $84 \%$ no ano de 2003 (Ilišin, 2007). Na Turquia, Sayari e Hasanov (2008) avaliaram as eleiçôes para deputados em 1999, 2002 e 2007, encontrando índices sempre acima de 90\%. Segundo Serna e Bottinelli (2009), $66 \%$ dos senadores e $63 \%$ dos deputados que tomaram posse em 2005 no Uruguai tinham curso superior, contra apenas $9,5 \%$ da população.

No Brasil, os autores também encontraram índices altos de formação superior dos deputados em diferentes momentos da história, a saber: $87,8 \%$ no período de 1946 a 1967, 91,3\% entre 1967 e 1987 e $84,8 \%$ entre 1987 e 1999 (Santos, 2000); 82,2\% em 1999 (Rodrigues, 2002); 80,5\% em 2006 (Perissinotto e Miríade, 2009); 81,4\% em 2006 (Braga, Veiga e Miríade, 2009). No Senado, índices semelhantes foram encontrados: $76,1 \%$ no Império (Carvalho, 2010); 97\% na década de 1990 (Lemos e Ranincheski, 2001); 88,7\% no período de 1987 a 2007 (Neiva e Izumi, 2012).

A formação em Direito é uma das mais frequentes (Best e Cotta, 2000; Carvalho, 2010; Culic, 2006; Patterson, 1968; Uriarte, 1997; Weber, 1999). De acordo com dados da Interparliamentary Union (IPU), profissionais com esse tipo de formação chegavam a $43 \%$ dos membros da câmara baixa nas Filipinas, 34\% no Chile, 29\% na Argentina, 23\% na Grécia e 17\% na Bélgica. Nos Estados Unidos, segundo Herrnson (1997), eles chegaram a ocupar 34\% da câmara baixa e $47 \%$ da câmara alta; Matthews (1984) fala em patamares em torno de $40 \%$ a $65 \%$, desde 1789 . No Brasil, foram encontrados percentuais de 8,8\% e 27\%, na Câmara dos Deputados e no Senado, respectivamente (Neiva e Izumi, 2012; Perissinotto e Miríade, 2009).

Entre outras, os autores apresentam as seguintes justificativas para essa situação: familiaridade com a lei e com a administração do Estado; treinamento com o uso da palavra, falada e escrita; prática da negociação e da conciliação; flexibilidade na administração do tempo, isto é, a facilidade com que os advogados podem conciliar a política com um emprego de tempo parcial; segurança financeira; facilidade para voltar a exercer a profissão - no caso de perderem o cargo político; familiaridade com as questōes legais; prestígio social (Dogan, 2003; Weber, 1999).

Outras profissóes que envolvem a habilidade de expressão, convencimento, sedução, argumentação e de uso da oratória também costumam ser comuns em diversos parlamentos no mundo (Rodrigues, 2002). É importante que ofereçam tempo livre e/ou flexibilidade no horário de trabalho, sem grandes prejuízos para a renda pessoal. Uma delas é a exercida pelos professores, que ocupavam $11 \%$ das cadeiras de deputados na Argentina, 6,6\% no Brasil, 7,8\% no Chile e 9,5\% no Uruguai, durante a década de 1990 (Santana, 2008). Nos Estados Unidos, contavam com $10 \%$ de representação, embora equivalessem a apenas $2 \%$ da população (Herrnson, 1997). Incluem-se nessas características os profissionais de comunicação, que foram menos estudados, mas chegaram a ocupar $6,4 \%$ das cadeiras na Câmara dos Deputados brasileira em 1999 (Rodrigues, 2002). 
Ocupações de prestígio na sociedade também costumam contar com uma grande quantidade de representantes. Os profissionais de saúde, por exemplo, ocupavam cerca de $8 \%$ das vagas de deputados na Argentina, 11\% no Brasil, 5\% no Chile e $8 \%$ no Uruguai durante a década de 1990 . Os engenheiros chegaram a ocupar mais de $16 \%$ das cadeiras de deputados no Chile no período de 1990 a 2001 (Santana, 2008).

Também frequente entre os parlamentares são as profissóes que proporcionam grande disponibilidade de recursos, já que estes podem ser aplicados para financiamento de campanhas eleitorais. Estamos falando dos empresários, rurais e urbanos. $\mathrm{Na}$ Grã Bretanha, responderam conjuntamente por $25 \%$ das cadeiras entre 1945 e 1974 (Mellors, 1978). Nos Estados Unidos, eram 24\% em 1992; na Austrália chegaram a 22\% em 1987; na Suíça, 12\% em 1991; na Nova Zelândia, 20\% em 1990; $24 \%$ no Reino Unido em 1992. Na Argentina e no Chile, os empresários urbanos também preenchiam um espaço político importante na década de 1990, chegando a ocupar $11 \%$ e $12 \%$ das cadeiras da câmara baixa, respectivamente. $\mathrm{O}$ mesmo pode ser dito dos produtores rurais, que chegaram a ter mais de $12 \%$, quando se consideram os dois países juntos (Santana, 2008). No entanto, patamares mais baixos também são encontrados: na França e no Japão, responderam por apenas $6 \%$ da Casa, em 1986 e 1990, respectivamente (Rodrigues, 2002); nos Países Baixos, por cerca de 5\% (Secker, 2000); no Brasil, ocupavam apenas 5\% das cadeiras da Câmara dos Deputados em 1990 (Santana, 2008).

Os servidores públicos também merecem destaque. Em percentual menor, costumam estar presentes em muitos parlamentos no mundo. Na década de 1990, ocupavam 5,2\% das cadeiras na Câmara dos Deputados argentina, 3\% no Brasil, 3,8\% no Chile e 3,6\% no Uruguai (Santana, 2008).

\section{Apresentação dos dados e questóes metodológicas}

O banco de dados que estamos usando nessa pesquisa abrange toda a história do Senado brasileiro, envolvendo 54 legislaturas. ${ }^{5}$ Isso foi possível a partir do oferecimento das informações na página do Senado na internet, que foram coletadas uma a uma. Consideramos as profissōes exercidas pelos

Tabela 1

Profissóes de Senadores - 1826 a 2010

\begin{tabular}{lll}
\hline Profissão/Ocupação & Proporção do Total (\%) & Como Profissão Única (\%) \\
\hline Advogados & 17,6 & 16,1 \\
\hline Empresários Rurais & 6,9 & 5,2 \\
\hline Empresários Urbanos & 11,4 & 12,7 \\
\hline Engenheiros & 4,3 & 6,9 \\
\hline Funcionários Públicos & 9,6 & 4,9 \\
\hline Magistrados & 5,2 & 2,6 \\
\hline Militares & 4,2 & 7,3 \\
\hline Outros & 9,1 & 6,9 \\
\hline Professores & 12,4 & 3,5 \\
\hline Profissionais da Comunicação & 10 & 14 \\
\hline Profissionais da Saúde & 7,2 & 9,7 \\
\hline Sem informação & 2,1 & 10,2 \\
\hline $\mathrm{N}$ & 2792 & 577 \\
\hline
\end{tabular}

Fonte: Banco de dados montado pelos autores a partir de informações contidas na página do Senado na internet. 
senadores que tomaram posse no primeiro ano de mandato de cada legislatura, ainda que tenham sido reeleitos ou que não tenham permanecido na instituição por muito tempo.

No total, passaram pela Casa 1415 senadores, entre titulares e suplentes. Nossa unidade de análise é o senador por profissão, por legislatura. Como muitos deles participaram de mais de uma legislatura e exerceram (ou se identificaram com) mais de uma profissão, o total de observaçôes ultrapassa esse número, chegando a 2.792. Na Tabela 1, apresentamos algumas estatísticas sobre cada uma das categorias profissionais, agregando todos os 186 anos de análise.

Poucas casas legislativas no mundo foram investigadas por um período tão longo. No livro organizado por Best e Cotta (2000), provavelmente a maior iniciativa nesse sentido, apenas a Noruega contava com um período de tempo mais extenso (de 1814 a 2004). A despeito da sua riqueza, nossos dados não estão livres de problemas. O primeiro tem a ver com o tamanho relativamente pequeno do Senado, que nos obrigou, algumas vezes, a trabalhar com poucas unidades de observação. Ainda que tenha sido possível verificar tendências gerais e padrôes específicos por período histórico, nem sempre o número de casos nos permitiu tirar conclusões taxativas.

O segundo problema refere-se ao fato de que as categorias ocupacionais mudaram substancialmente ao longo do tempo, seja na sua diversidade, na sua natureza, seja no seu prestígio ou no reconhecimento perante a sociedade. A de proprietário rural, por exemplo, é diferente hoje do que era há um século ou mais: as propriedades foram reduzidas, passaram a utilizar tecnologia avançada, produzem para um mercado bem mais sofisticado e as relações de trabalho no campo mudaram substancialmente. No período inicial do Império, os médicos eram formados em Portugal e eram bem menos especializados do que atualmente. Os professores passaram por um processo de "deselitização" evidente. A engenharia profissionalizou-se e tornou-se especializada, abrangendo hoje diversos campos de aplicações que vão desde áreas tradicionais como a civil, a elétrica, a militar e a naval até as mais recentes, tais como a nuclear, a aeronáutica, a robótica, a mecatrônica e a computação. Algumas profissões nem existiam no século XIX, como a de psicólogo, por exemplo; outras, como as de artesão e de caixeiro viajante, praticamente desapareceram. Paralelamente, em anos recentes, o Senado tornou-se uma casa um pouco menos elitista, passando a contar em seus quadros com profissionais socialmente menos prestigiados, tais como bancários e seringalistas.

Outro problema a ser considerado é que a formação acadêmica em uma área, muitas vezes apresentada pelo parlamentar como profissão, não gera necessariamente uma única atuação profissional. Particularmente relevante no caso brasileiro é a diferenciação feita por José Murilo de Carvalho (2010) entre os magistrados e os advogados - ambos com formação em Direito - na composição da elite política do Império. Tampouco o título acadêmico garante que o seu detentor irá utilizá-lo com a finalidade a que se propõe. Diversos são os casos, por exemplo, de engenheiros que acabam executando atividades profissionais na área da economia, em função da facilidade que possuem com a matemática e disciplinas afins.

Não podemos esquecer também que a própria representação mudou: no Império, os senadores eram escolhidos pelo imperador, a partir de uma lista tríplice dos mais votados pelos eleitores; portanto, não representavam a população em geral, seja em termos ocupacionais, seja politicamente. Na República, foram escolhidos em diversos contextos, sob regimes ditatoriais ou democráticos. Em 1974, após a outorga de um conjunto de leis pelo governo autoritário, um terço dos senadores passou a ser escolhido pelo presidente da República, a partir de uma lista apresentada por um colégio eleitoral composto por membros das respectivas assembleias legislativas estaduais e delegados de câmaras municipais.

Outra dificuldade que encontramos foi na definição das categorias de classificação. Em primeiro lugar, por conta da sua diversidade: encontramos nada menos que noventa profissões diferentes no período analisado. Em parte, o problema foi reduzido ao agregarmos aquelas que eram claramente próximas. Por exemplo, médicos, dentistas e farmacêuticos foram agrupados em uma única categoria chamada "profissionais da saúde". No final, ficamos com apenas onze categorias profissionais. 
Cabe registrar também o problema da ocorrência frequente de profissões múltiplas por um único parlamentar, isto é, o fato de a mesma pessoa exercer mais de uma profissão ao mesmo tempo. No intuito de aumentar seu eleitorado e a abrangência de sua representação, os legisladores costumam declarar uma gama ampla de atividades. Identificamos, por exemplo, senadores que ocuparam cargos de advogado, professor, médico e jornalista ao mesmo tempo; ou de médico, farmacêutico, agropecuarista e professor.

Para resolver o problema, os autores recorrem a estratégias diferentes. Carvalho usou como critério o grau de impacto que, em sua opinião, a ocupação poderia ter sobre o indivíduo no que se refere à atitude para com o Estado e a capacidade para exercer cargos públicos. Nas palavras do autor, "tratava-se de decidir que ocupações tenderiam a desenvolver orientaçôes favoráveis ao fortalecimento do Estado, e dar-lhes preferência para a classificação" (2003, p. 99).

Ainda que defensáveis, os critérios utilizados pelos diferentes autores nem sempre contornam o problema e nem evitam que outros apareçam. Carvalho (2010), por exemplo, classificou os padres, os professores e os magistrados que não chegaram a juiz de direito em categorias separadas, ainda que fossem também servidores públicos e, a rigor, devessem ser classificados como tal. Além disso, o autor agregou numa única categoria, que chamou de "profissionais liberais", advogados, médicos, engenheiros, professores de ensino superior e jornalistas, embora exercessem funções muito diferentes e vários deles fossem também funcionários públicos. Além disso, classificou em um mesmo grupo segmentos tão distintos quanto os proprietários rurais, comerciantes, banqueiros e industriais.

No nosso caso, visualizamos três opções de classificação. A primeira seria definir qual era a profissão principal do senador, caso a caso. De início, descartamos essa opção, dado o grande número de indivíduos do nosso banco de dados e o risco de que tal definição fosse feita a partir de critérios essencialmente subjetivos. Além disso, poderíamos incorrer nos mesmos problemas enfrentados por Carvalho (2010), com o agravante de que estamos trabalhando com um período de tempo bem mais extenso - quase dois séculos - durante o qual as profissões se tornaram bem mais complexas e mudaram de configuração.

Uma segunda possibilidade seria a de selecionarmos apenas os senadores que tinham uma única profissão. Nesse caso, perderíamos $60 \%$ da nossa população de senadores. Além disso, necessitaríamos ter a segurança de que a informação sobre profissão única era, de fato, verdadeira e de que não estaria enviesada por falta de informação.

A opção que elegemos - também escolhida por Rodrigues (2002) no seu estudo sobre os deputados - consistiu na consideração de todas as profissões apresentadas na nossa fonte de dados. Com isso, caímos no problema de que alguns senadores acabam tendo peso maior: $60 \%$ deles contam com mais de uma profissão, chegando a ter até quatro ou cinco diferentes em alguns casos extremos. Não é a situação ideal, mas ela evita que se defina incorretamente qual é a ocupação principal do senador ou que algumas ocupaçôes sejam desprezadas e outras sejam sobrevalorizadas. Afinal, se estamos trabalhando com uma Casa representativa, é importante termos em conta que o representante frequentemente não representa um único segmento ou setor. Ainda que não possamos falar em representação democrática em grande parte do período analisado, supomos que os senadores expressavam interesses específicos, seja do imperador, seja das elites ou grupos a que estavam ligados, seja dos eleitores que os escolhiam.

Utilizamos o método prosopográfico, ou método das biografias coletivas, o qual adota um enfoque de cunho sociológico na pesquisa histórica. Ele ajuda a revelar as características e a elaborar perfis de determinados grupos sociais e categorias profissionais em um dado período histórico, dando destaque aos mecanismos coletivos de recrutamento, seleção e reprodução, que caracterizam as trajetórias sociais (e estratégias de carreira) dos indivíduos (Heinz, 2006). O propósito é trazer novos elementos à interpretação histórica, às mudanças sociais e aos momentos de transição política. Nesse sentido, procuramos regularidades e sinais comuns nos senadores de uma mesma época. Por outro lado, as informações históricas também podem nos ajudar a explicar a ocorrência maior ou menor de profissões específicas. 


\section{Profissóes dos senadores brasileiros - 1826 a 2010}

Em uma análise longitudinal desse tipo, diversas perspectivas analíticas podem ser utilizadas. Uma delas é tratar o conjunto dos dados como um todo, procurando verificar o nível geral de variação. Isso pode ser feito por meio da avaliação das mudanças de uma legislatura em relação à que vem imediatamente posterior. Nesse intuito, apresentamos os gráficos de todas as profissões em uma única página no Apêndice 1. Conforme se observa, mudanças bruscas quase não aconteceram nesses quase dois séculos de história do Senado. Verifica-se um aumento importante dos militares (de 6,2\% para $8,7 \%$ ) entre a última legislatura do Império e a primeira do regime republicano, bem como uma queda substantiva dos servidores públicos (de 23,3\% para 10,5\%) no mesmo período. No entanto, movimentos desse tipo foram raros e não chegaram a ser absurdamente expressivos. Quase sempre, as alterações foram gradativas e sequenciadas. Em geral, a mudança na proporção ocupada por cada categoria profissional, de uma legislatura para outra, foi baixa.

Outra possibilidade analítica é a de compararmos a estabilidade - ou mudanças entre legislaturas subsequentes - dos intervalos históricos entre si. Não há um padrão claro nos períodos mais recentes: do Estado Novo até a atualidade. Uma diferença mais perceptível pode ser vista quando se compara o período imperial com a Primeira República, que o sucede. É clara a maior estabilidade no primeiro. A explicação provável deve-se ao fato de serem os mandatos vitalícios naquele período: geralmente, os senadores só eram substituídos por vontade do monarca, por doença ou morte. Se havia menos substituição de indivíduos, era natural que houvesse menos alteração dos grupos profissionais; em outras palavras, se a taxa de circulação pessoal era menor, a taxa de circulação social também deveria sê-lo.

O mesmo já não acontece na República Velha, quando fica evidente a maior instabilidade de algumas categorias profissionais, a saber: advogados, professores, comunicadores, militares, profissionais da saúde e outros. Os dados sugerem que havia menos unidade consensual entre as elites nacionais desse período, comparado com o período imedia- tamente anterior. Além da taxa de renovação maior dos senadores, ${ }^{6}$ cabe considerar a complexidade daquele momento, marcado por revoltas armadas e forte divisão de opinião entre os atores: parlamentarismo versus presidencialismo, monarquia versus república, centralismo versus federalismo, liberalismo versus positivismo.

No entanto, de uma maneira geral, as variaçóes no curto prazo são pequenas. Ao menos no que diz respeito às mudanças profissionais, essa perspectiva de estabilidade parece confirmar os propósitos dos pais fundadores dos Estados Unidos, quando projetaram a câmara alta daquele país. A ideia era a de criar uma casa "onde predominasse a prudência, que evitasse o impulso de paixões violentas, as resoluções perniciosas e a sedução por lideranças destemperadas" (O Federalista, 62) (Hamilton, Madison e Jay, 2005). Nesse intuito, o Senado foi configurado de forma diferente da câmara baixa: tamanho menor, idade mínima superior, mandato com maior duração, renovação parcial dos seus membros. Ainda que haja diferenças importantes em relação ao que foi feito no Brasil no período imperial, ${ }^{7}$ é evidente a influência norte-americana sobre a configuração das instituições brasileiras, inclusive no que diz respeito à câmara alta (Neiva, 2006).

Se as variações de uma legislatura para outra são pequenas, o mesmo não pode ser dito no longo prazo. Nas subseções que se seguem, avaliamos a evolução de categorias profissionais importantes, recorrendo tanto aos gráficos de cada uma delas, quanto à tabela de suas respectivas médias por período históricos, apresentada no Apêndice 2.

\section{Profissionais do Direito}

A exemplo do que acontece na maioria dos países, profissionais com formação em Direito tem sido a categoria mais frequente na elite política brasileira. Nos primeiros anos do Império, eles eram formados em Portugal, quase todos em Coimbra. Segundo Carvalho (2010), esse teria sido um fator de homogeneização da elite, que não aconteceu nas colônias espanholas, onde foram criadas universidades e onde predominava a formação religiosa. A partir de 1828, com a criação de uma faculdade de Direito em São Paulo e outra em Olinda/Recife, 
esses profissionais passaram a ser formados também no Brasil. Na opinião de Venâncio Filho (1982), eles foram fundamentais para o movimento de independência e constituíram uma elite política que conduziu o país durante o Império; nesse período, nada menos que 147 (67\%), das 219 pessoas que ocuparam cargo de ministro, tinham esse tipo de formação. Carvalho (2010) apresenta números ainda maiores para o mesmo período: $72,5 \%$ dos ministros tinham formação jurídica ${ }^{8}$ no entanto, com a proclamação da República, perderam parte do seu prestígio, em favor dos militares. O Gráfico 1 mostra que situação semelhante aconteceu no Senado. Os profissionais do Direito foram, e continuam sendo, a categoria mais frequente na Casa.

Conforme se observa, houve uma diminuição de profissionais com essa formação ao longo do tempo. No Império, ocuparam em média 29,5\% das cadeiras do Senado, se juntarmos nesse grupo os advogados e os magistrados, que atingiram percentuais de $15,2 \%$ e $14,3 \%$, respectivamente (ver Apêndice 1). Nas décadas finais do período monárquico, chegaram a responder por mais de um terço das cadeiras. Reduziram a participação para um patamar abaixo de 30\% durante a Primeira República e caíram ainda mais durante o Estado Novo, man- tendo a participação ao redor de $20 \%$ até o final do século XX. Nas três últimas legislaturas, já no século XXI, diminuíram um pouco mais, passando para um patamar levemente acima de $10 \%$.

Essa trajetória descendente dos profissionais do Direito foi observada em diversos outros países (Serna, 2009). Na Alemanha, Wessel (1997) verificou que não existe mais o monopólio dessa categoria no Legislativo: a proporção de indivíduos com formação jurídica caiu de 50\% para 30\% no período compreendido entre os anos 1960 e os 1980. Na França, os parlamentares com tal formação diminuíram a sua participação de 29\% em 1898 para 24\% no período entre guerras e para 13\% na Quarta República, instaurada em 1946. Na Itália, ocupavam 42\% das cadeiras da câmara baixa no início dos anos de 1920 , caindo para $21 \%$ quatro décadas depois (Patterson, 1968). Na Suiça, Pilotti et al. (2010) verificaram que o número caiu de $73 \%$ para $46 \%$ entre 1910 e 2000. Na Câmara dos Deputados no Brasil, Santos (2000) identificou uma participação bem maior do que a que estamos observando aqui: $57 \%$ dos deputados eram diplomados em Direito durante a República de 1946, subiram para $61 \%$ durante o regime militar, mas baixaram para cerca de $40 \%$ na Nova República. Dados mais recentes mostram

Gráfico 1

\section{Profissionais do Direito}

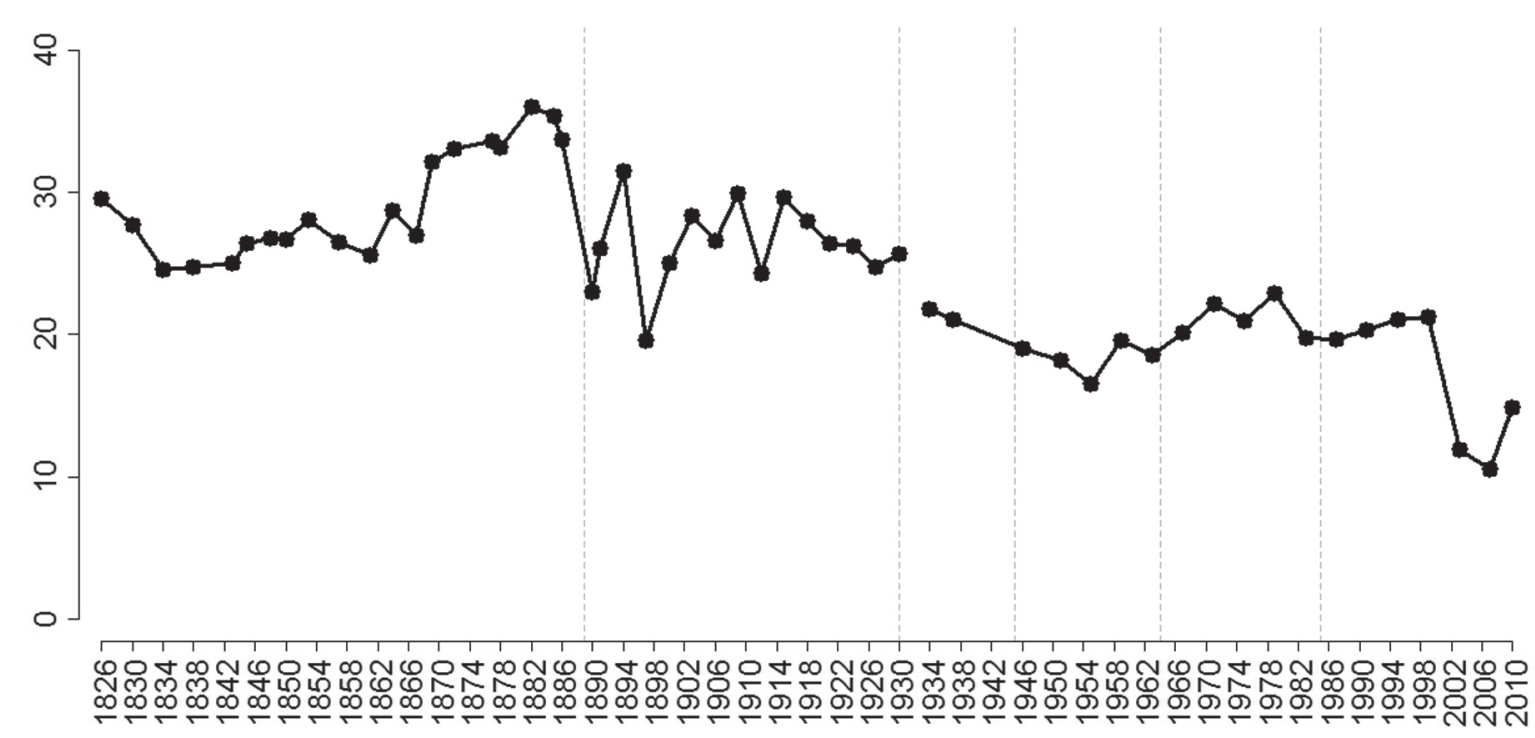


que esses números caíram substancialmente para $15,4 \%$ em 1998, 14,6\% em 2002 e 8,8\% em 2006 (Bolognesi e Perissinotto, 2011).

Uma explicação para a redução desses profissionais nos legislativos pode ser creditada ao processo de democratização e de inserção de novas categorias sociais na representação política. Segundo Best e Cotta (também Serna, 2009), os advogados aparecem em "estágios transitórios, quando a democracia ainda não se concretizou [...] e onde as leis eleitorais são restritas e os partidos são fracos" (Best e Cotta, 2000, p. 524). De acordo com Matthews (1984), o número de advogados reduziu-se com o advento de partidos políticos com bases classistas na Dinamarca, até chegar ao nível de $4 \%$ em anos recentes. Na mesma linha, Wences (1969) encontrou relações negativas entre o comparecimento dos eleitores às urnas e o número de parlamentares empresários e advogados. Encontrou ainda relação positiva entre a participação eleitoral e a ocupação de cargos de líderes sindicais e de profissões não ligadas à área do Direito.

Em função da distinção feita por José Murilo de Carvalho (2010) entre magistrados e advogados, decidimos separar os dois grupos em categorias diferentes. De acordo com o autor, os primeiros estiveram mais presentes em Portugal e no Brasil colonial. Eram quase sempre formados na Universidade de Coimbra, uma instituição profundamente influenciada pela tradição romanista. Tratava-se, segundo ele, de um grupo identificado com a manutenção da ordem e a supremacia dos interesses do Estado. $\mathrm{Na}$ opinião de Silveira (2009), foram peças centrais na articulação dos interesses do Reino e da elite, na manutenção da estabilidade social e do equilíbrio institucional do país no período monárquico.

Já os advogados desempenharam um papel peculiar na política dos países que passaram por uma revolução capitalista e burguesa. Nos Estados Unidos, eram fundamentalmente representantes dos interesses privados, especialmente dos empresários, que não tinham tempo para se dedicar às atividades políticas. Contrastavam com os servidores públicosincluindo os magistrados -, que eram vistos com suspeição e desapreço, dada a sua imagem ligada ao passado colonial. O Gráfico 2 mostra que essa diferença entre os dois grupos de profissionais aparece no Senado brasileiro.
Conforme podemos observar, a presença dos magistrados foi muito mais intensa nos primeiros anos do Império, quando chegaram a ocupar mais de $20 \%$ da Casa. Isso corrobora a afirmação de Carvalho (2010, p. 99), de que eles foram os mais completos construtores do Estado durante o período imperial, especialmente os da geração formada em Coimbra. Depois desse período, caíram progressivamente ao longo do tempo, até a sua quase ausência nas últimas décadas. Uma explicação possível para essa situação deve-se ao fato de que, durante o Império, não havia independência do Judiciário, de modo que instituições jurídicas e políticas não se separavam em duas possibilidades alternativas de carreira, daí terem se afastado da política. Cabe acrescentar que tal constatação veio combinada com uma guinada dos magistrados na sua atuação e na relação com o Estado, em função de sua composição bem mais heterogênea: mais jovem, com maior participação feminina, de origem social diversificada, com elevado índice de mobilidade social ascendente, com formação em faculdades distintas, orientação plural, visão mais crítica, sem partilhar uma socialização comum (Vianna et al., 1997).

Já os advogados ocuparam um espaço um pouco menor nos anos iniciais do Império (em torno de $10 \%$ ), mas a sua participação cresceu substancialmente a partir de 1864, ultrapassando o percentual de $20 \%$ no final do período imperial. Com algumas oscilaçōes durante a Primeira República, manteve-se próximo a esse patamar até o final do século XX, quando caiu substancialmente na eleição de 1998 , de $19 \%$ para $10 \%$.

Esse último movimento sozinho não é suficiente para tirarmos conclusões taxativas, mas ele está de acordo com a sugestão de que "uma democracia de massas em um contexto com alta polarização ideológica não é um ambiente muito favorável para o 'empreendedor político livre', usualmente encarnado nos advogados" (Cotta e Best, 2000, pp. 524-525). Ela se explica também pelo crescimento dos partidos de esquerda nas últimas eleiçōes para o Senado, já que a profissão de advogado costuma estar conectada com as classes sociais mais elevadas e com partidos de direita (Ruostetsaari, 2000) ou de centro (Braga et al., 2009). 


\section{Gráfico 2}

Advogados e Magistrados

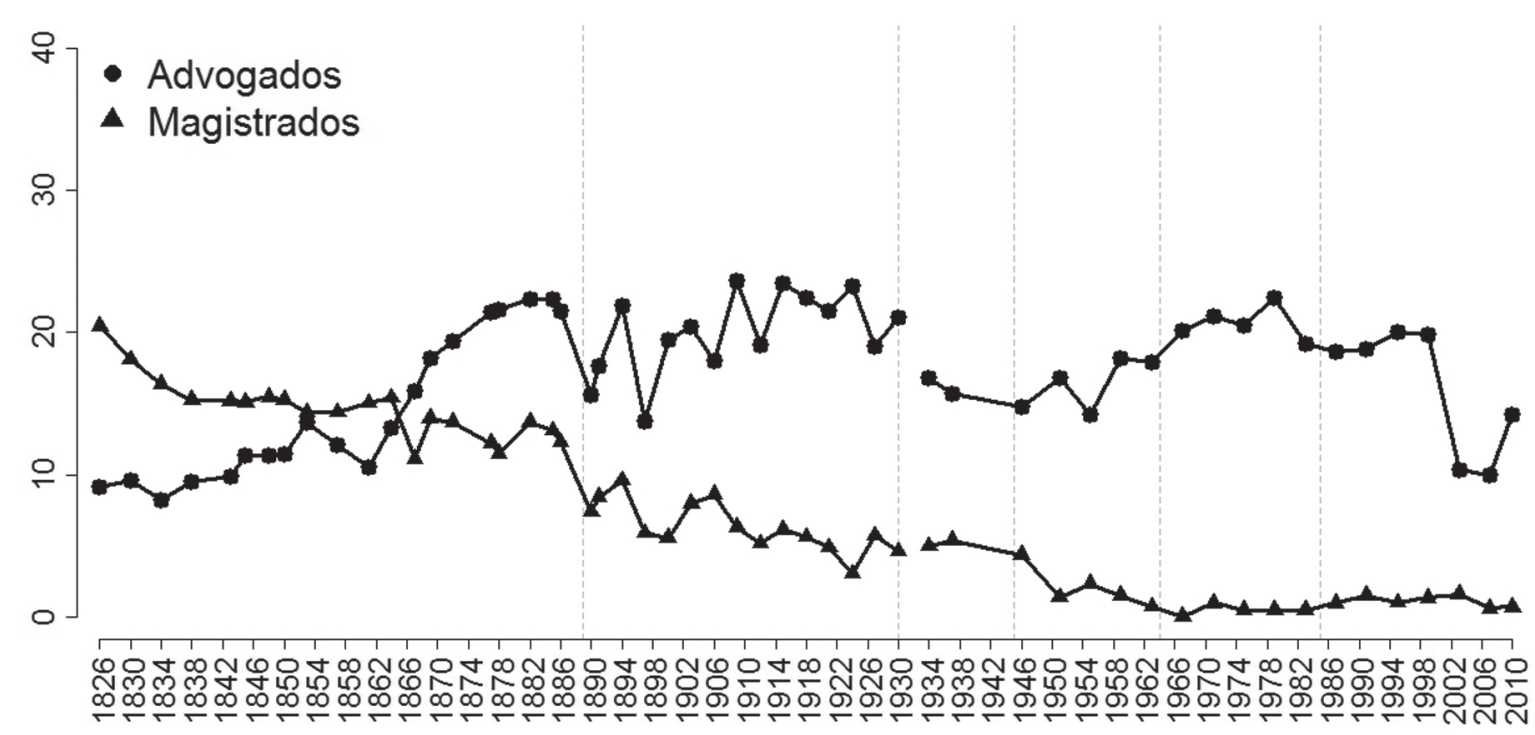

\section{Militares}

Os militares também tiveram uma presença bem demarcada por períodos históricos. O Gráfico 3 mostra a sua evolução ao longo do tempo.

Conforme se observa, os militares contavam com participação relativamente alta no Senado (em torno de 13\%) no início do Império, um período conturbado e marcado por diversas revoltas e insurreiçôes, entre as quais: Guerra da Cisplatina, Cabanagem, Revolução Farroupilha, Balaiagem, Insurreição Praieira. Essa presença caiu até o final do período imperial, chegando a valores bem baixos: ao redor de $4 \%$ dos membros da Casa.

Esses dados mostram o pouco prestígio que gozavam junto ao imperador Dom Pedro II, que governou o país após 1840 , reforçando a percepção de outros autores sobre o tema. Segundo Carvalho (2003, p. 55), "o governo imperial foi profundamente civil", restando ao Exército reduzida influência sobre as decisões da política nacional no período compreendido entre 1831 até o início dos anos de 1880. De acordo com Leite (1978), Dom Pedro II não tinha atração pelos militares, o que explica a distância que a classe ficou do poder durante o seu mandato. Segundo a autora, apenas quatorze militares ocuparam a pasta da guerra durante o segundo reinado, contra 25 ministros civis no mesmo cargo. De 1840 a 1850, sete militares foram membros do Conselho de Estado; nos 39 anos posteriores, apenas três ocuparam tão elevado posto. Em 1889, ano da proclamação da República, não havia nenhum deles no grupo.

Por outro lado, os militares também não se simpatizavam com a monarquia e acabaram se constituindo no principal elemento da destruição do sistema. Excluídos do processo político dominado pelos civis, insatisfeitos com o baixo status que lhes foi conferido como ator social e conscientes de sua força após a Guerra do Paraguai, eles reagiram intervindo na política e rompendo a ordem institucional (Carvalho, 2010). Na opinião de Leite (1978), o fortalecimento e o crescimento do prestígio do Exército geraram o apoio de civis para a sua participação na política, contribuindo em larga escala para o golpe de 1889.

Na primeira legislatura do período republicano - que se iniciou com dois presidentes militares - 


\section{Gráfico 3}

Militares

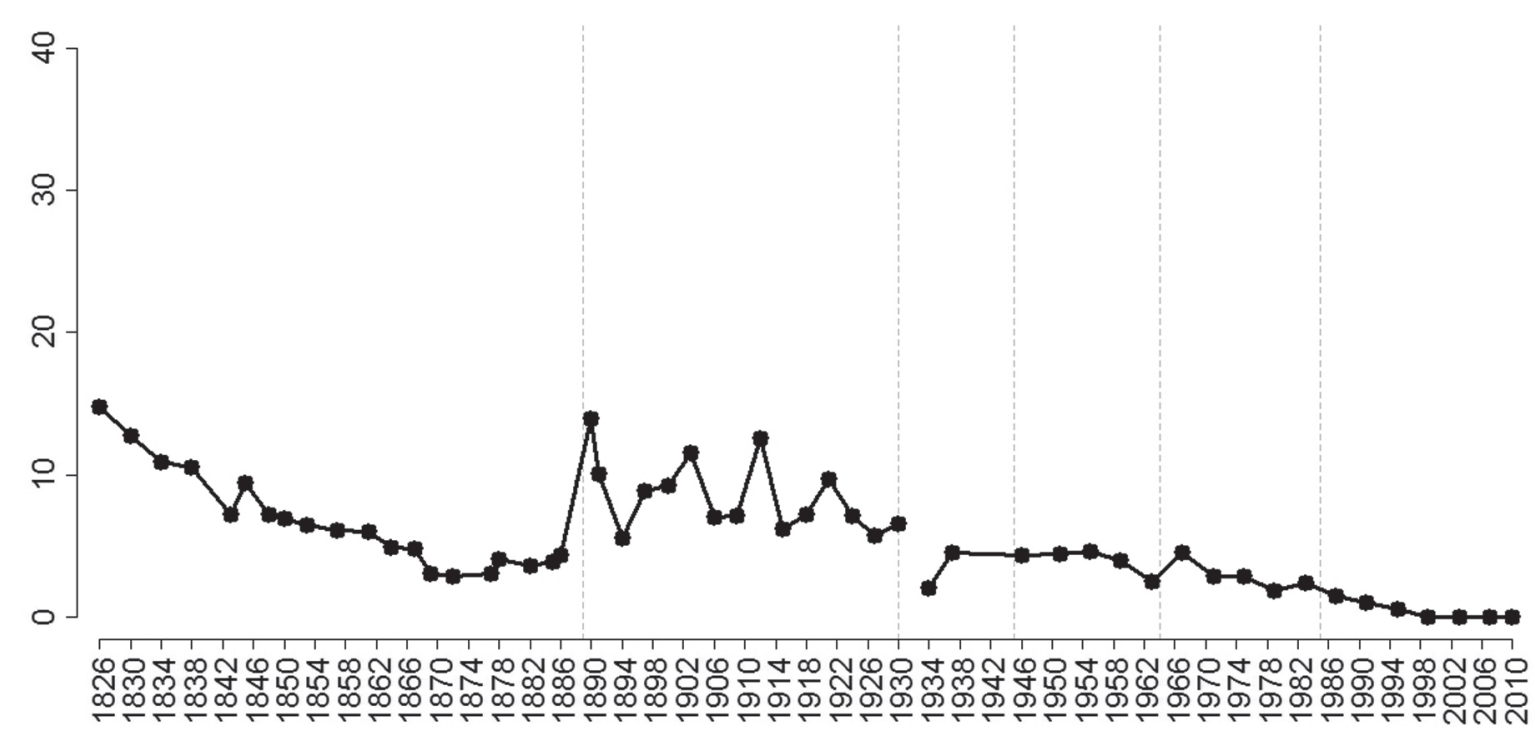

o grupo atingiu a proporção mais alta de toda a sua história, chegando a valores próximos de 15\%. A média de toda a República Velha ficou em torno de $9 \%$. Esse aumento pode ser creditado à politização da corporação, cuja identidade própria começou a ser formada desde os anos de 1850. Interessante notar que o aumento da participação dos militares se dá no mesmo momento em que cai a participação dos proprietários rurais, grupo com o qual tiveram conflitos constantes, especialmente na questão da abolição da escravatura (Carvalho, 2010; Schulz, 1994).

O Gráfico 3 mostra ainda que, após sofrer diversas oscilaçôes durante a Primeira República, o grupo chegou a patamares abaixo de $5 \%$ durante o Estado Novo. Daí por diante, decaiu paulatinamente, atingindo médias de 3,9\% e 2,8\% durante o regime democrático de 1946 a 1964 e da ditadura militar que a sucedeu, respectivamente, até chegar a nenhum representante na virada do século.

É curioso que os generais Geisel e Figueiredo escolheram civis para serem senadores "biônicos”, e não membros das Forças Armadas. Como a resistência aos militares já era expressiva no momento da edição do "Pacote de Abril", uma opção diferente naquele momento poderia complicar ainda mais a situação. Além disso, muitos dos "biônicos", tanto senadores como governadores, mantiveram-se em cargos importantes após a queda do governo militar, funcionando como elementos importantes no processo de transição negociada.

\section{Empresários urbanos}

No Gráfico 4, podemos observar a evolução da participação dos empresários urbanos no Senado brasileiro ao longo do tempo.

O gráfico mostra que os empresários têm aumentado a sua participação no Senado desde o seu início em 1826. Durante o Império, ocuparam um espaço muito pequeno: a média de todo o período ficou em apenas $2,8 \%$, confirmando os achados de Leite (1978). Isso mostra a aversão que Dom Pedro II tinha por homens de negócios; não é por acaso que apenas um comerciante chegou ao posto de marquês durante o seu governo (Carvalho, 2010, p. 54). 


\section{Gráfico 4 \\ Empresários Urbanos}

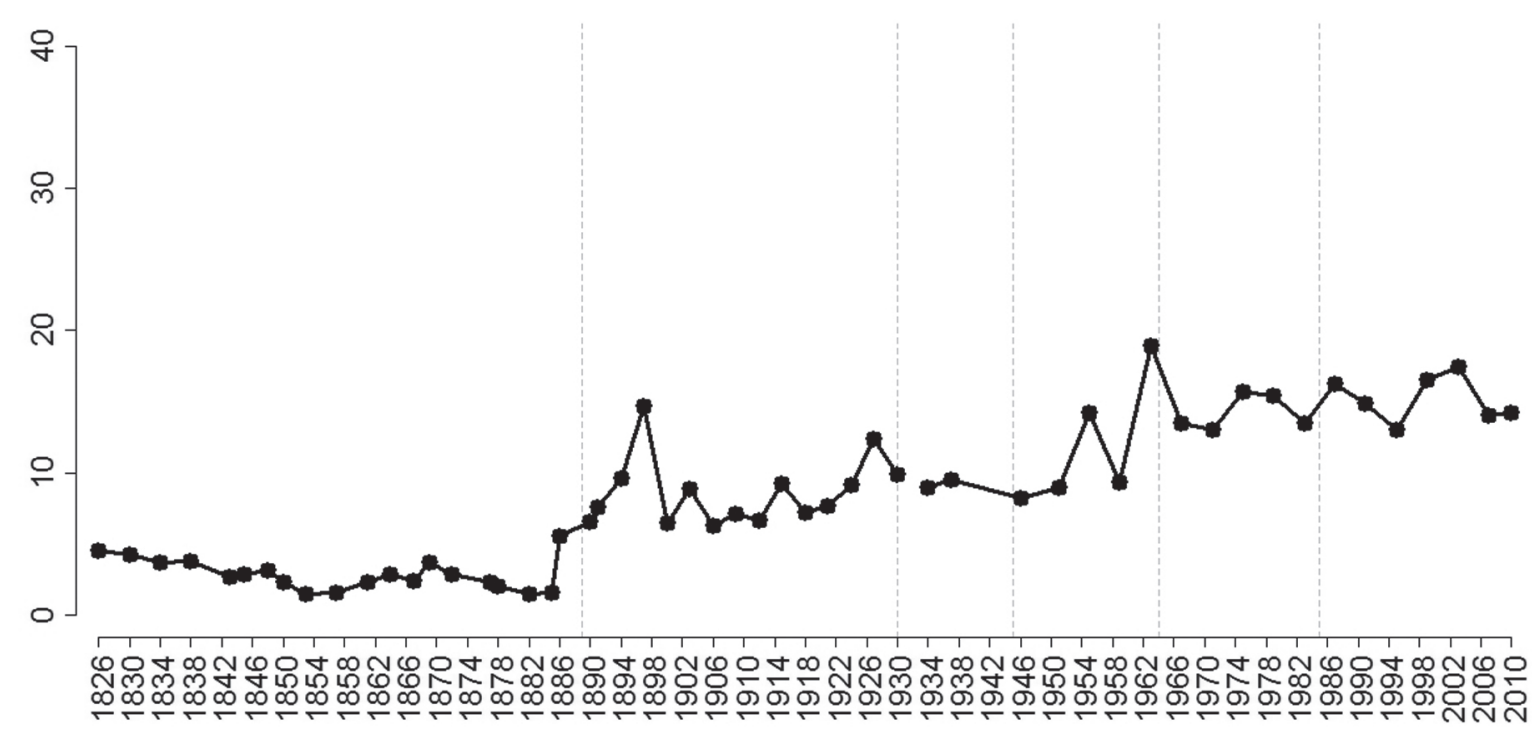

A ascensão da classe nos primeiros anos da República é bem evidente. Eles passaram de dois representantes em 1885 para nove em 1909, o que sugere um reforço da industrialização, uma das principais "bandeiras" dos oficiais militares politicamente ativos (Schulz, 1994). A participação média durante a Primeira República e o Estado Novo ficou em torno de $9 \%$ da Casa, subindo para $12,2 \%$ no período da República Populista e para mais de 14\% durante o regime militar e a Nova República. A queda nas duas últimas legislaturas (2006 e 2010) pode ter a ver com a conquista do poder nacional pelo Partido dos Trabalhadores; segundo Rodrigues (2002), a participação dos empresários nos parlamentos está relacionada com seu posicionamento ideológico e tende a aumentar com o crescimento dos partidos de direita.

Tais dados confirmam a afirmação de Diniz e Boschi (2000) de que a representação empresarial como um todo no Congresso nunca deixou de ser expressiva no período republicano. ${ }^{9}$ Eles estão bem abaixo, no entanto, dos números encontrados por Love e Barickman (2006): segundo os dois autores, $34 \%$ da elite política que comandou o país desde o início da República até o Estado Novo eram ho- mens de negócios. A partir dos nossos dados, calculamos as seguintes médias para os empresários (rurais e urbanos, em conjunto) por período histórico: Primeira República (12,8\%), Estado Novo $(15,2 \%)$, República Populista $(19,9 \%)$, regime militar (23,7\%), Nova República (19,7\%).

\section{Empresários rurais}

De acordo com teorias da modernização política, uma mudança de poder de elites rurais (ou vinculadas ao setor primário da economia) para elites urbanas (ligadas aos setores secundário e terciário) é um passo necessário na caminhada para uma democracia estável (Best Gaxie, 2000). De fato, em quase todos os países analisados no livro organizado por Best e Cotta (2000), houve uma queda expressiva dos parlamentares oriundos do setor rural no período compreendido entre os séculos XIX e XX. Na Dinamarca, por exemplo, detinham 54\% das cadeiras em 1901, decaindo sistematicamente até chegar a apenas 7\% em 1990 (Pedersen, 2000). Na Noruega, chegaram a ocupar $40 \%$ da câmara baixa em 1889, caindo desde então para apenas um representante no final 


\section{Gráfico 5 \\ Empresários Rurais}

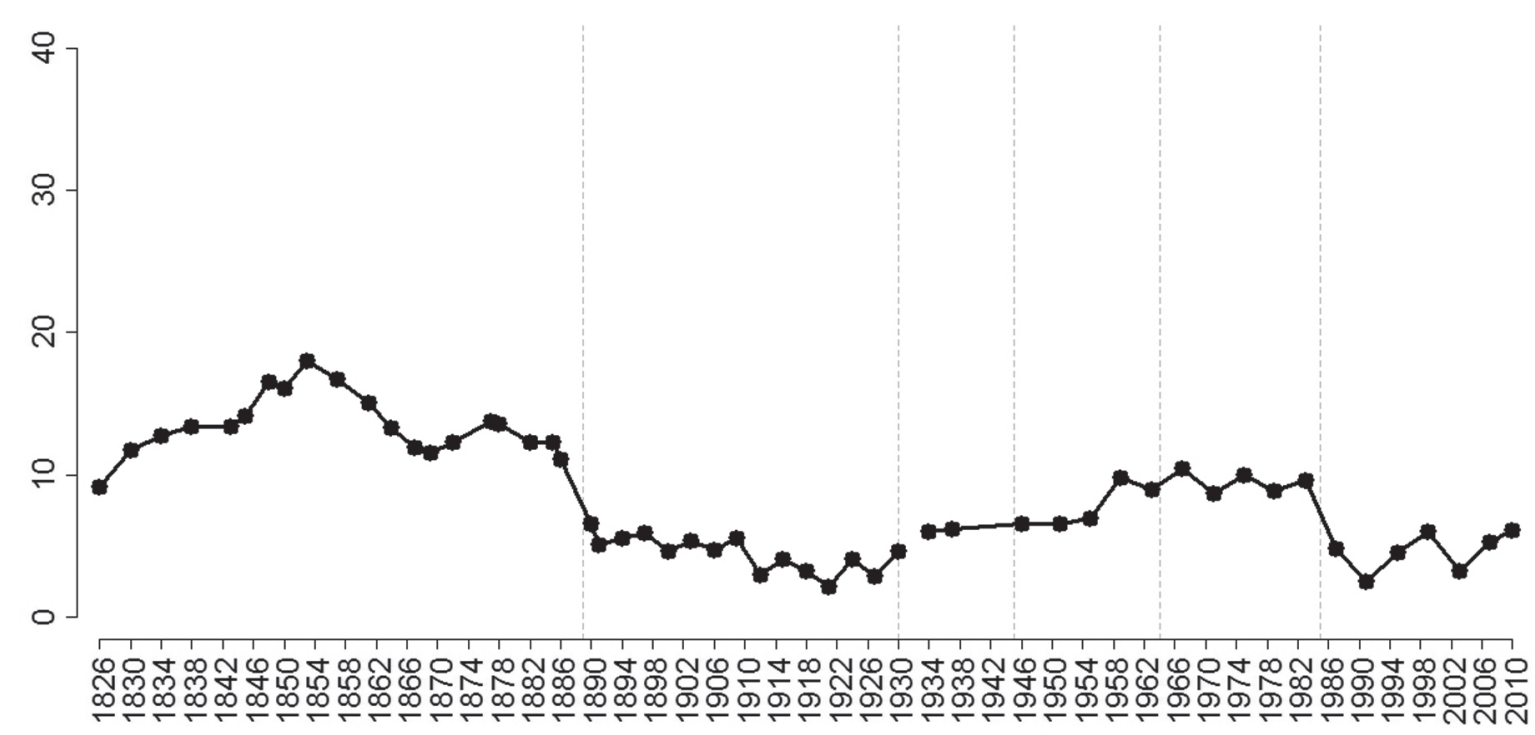

do século XX. No Reino Unido, saíram de 40\% em 1868 para nenhum representante a partir de meados da década de 1970 (Rush e Cromwell, 2000).

O Gráfico 5 mostra que, a exemplo do que aconteceu nos países europeus, os empresários rurais também reduziram a sua participação no Brasil, ao menos no que se refere à câmara alta. Chegaram a ocupar quase $20 \%$ da Casa em 1853 , período que coincide com a expansão da produção de café. Declinaram paulatinamente, até sofrerem uma queda brusca na transição do Império para a República. Embora a elite cafeeira continuasse forte, transformaçôes importantes estavam sendo processadas: substituição da mão de obra escrava pela dos imigrantes europeus, descentralização, extinção do Poder Moderador, separação entre a Igreja e o Estado, fortalecimento dos ideais positivistas, transferência de poder dos cafeicultores cariocas para os paulistas.

Ao olharmos o gráfico em uma perspectiva ampla, observa-se a participação substancialmente maior dos empresários rurais no período monárquico. Não é para menos, haja vista o amplo predomínio da economia agropecuária naquele período histórico. Carvalho relata bem essa situação:
A terra era a principal fonte de riqueza e de poder e seus proprietários figuras de prestigio [...] o Estado dependia profundamente $\mathrm{da}$ produção agrícola de exportação e não podia sustentar-se sem a agricultura, pois era ela que gerava $70 \%$ das rendas do governo-geral, via arrecadação de impostos. [...] Gostando ou não, a elite política tinha de compactuar com os proprietários a fim de chegar a um arranjo, que possibilitasse pelo menos uma aparência de ordem. O Brasil era uma economia de produtores agrícolas com mão-de-obra escrava e de criadores de gado (2010, p. 32).

Segundo Silveira (2009), não era raro que membros da aristocracia rural fossem recrutados para compor os quadros burocráticos de uma elite estatal dirigente. De acordo com o autor, muitas famílias detentoras de propriedades rurais e participantes do sistema escravocrata destinavam seus filhos mais velhos para cuidarem das economias da casa senhorial, enquanto os mais jovens eram estimulados a seguir uma carreira pública, como líderes políticos, senadores e deputados. 


\section{Gráfico 6}

\section{Proporção de Títulos Nobiliárquicos Distribuídos para os Senadores do Império}

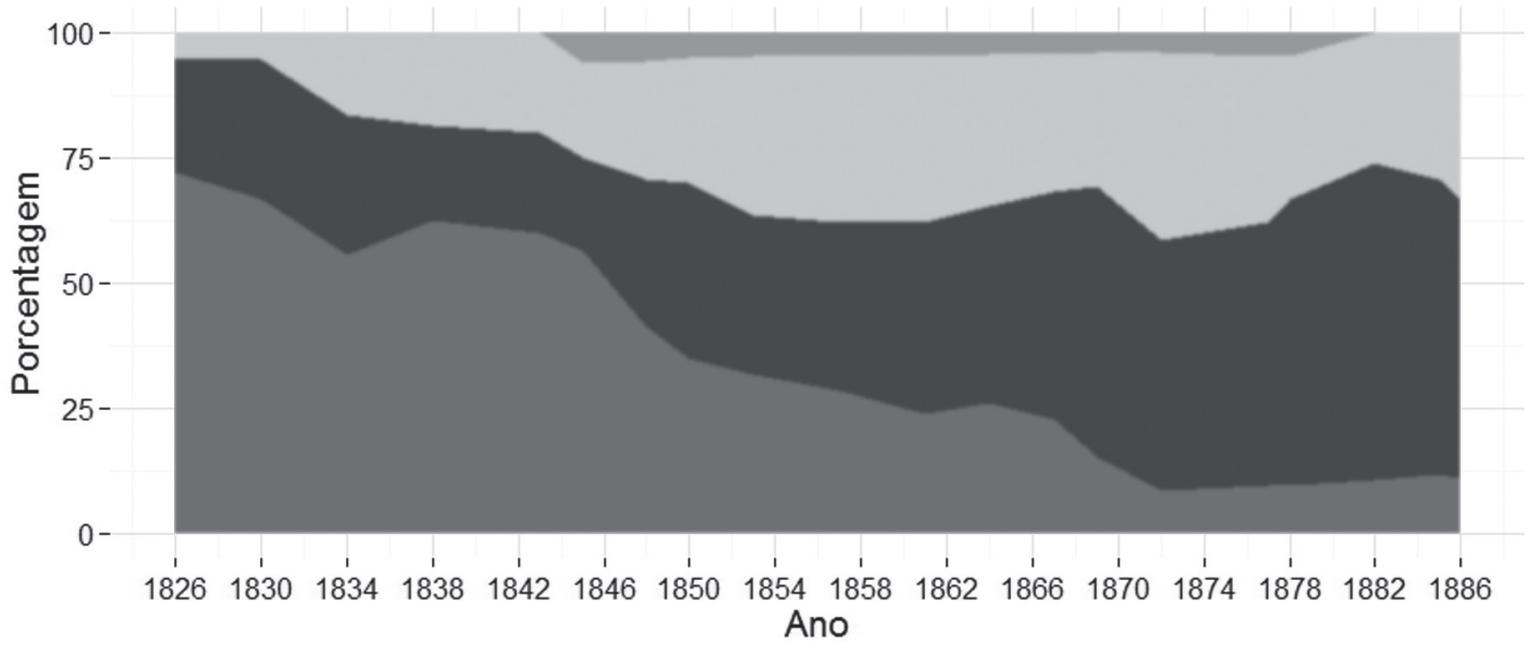

Barão Duque $\square$ Marquês $\square$ Visconde

Dado que os senadores eram escolhidos pessoalmente pelo monarca, o Segundo Reinado (18311889) torna-se importante para a nossa análise. Foi nele que se consolidou o movimento pela abolição da escravatura, especialmente a partir de 1850 , quando foi proibido o tráfico de negros no país. Uma das estratégias utilizadas por Dom Pedro II para amainar a resistência às medidas abolicionistas e aos movimentos republicanos, bem como manter a coesão social cooptando membros da elite, foi a distribuição de títulos de nobreza entre os proprietários rurais, especialmente os de barão e de visconde. Nada menos que 76,8\% dos títulos distribuídos por Dom Pedro II foram de barôes, contra 35,8\% de Dom Pedro I e $21 \%$ de Dom João VI. Nas palavras de Carvalho (2003, p. 258), "a Coroa tentava devolver em símbolo de status o que retirava em interesse material". Como grande parte da aristocracia rural estava concentrada no Senado, a distribuição desses dois títulos aumentou entre os senadores durante esse período. Conforme mostra o Gráfico 6, o seu crescimento foi expressivo a partir da sétima legislatura, que se iniciou em 1848. As áreas sombreadas mostram a proporção de cada uma das categorias nobiliárquicas concedidas aos senadores do período imperial.

Voltando ao Gráfico 5, verificamos que, durante a República, a explicação para a trajetória da curva de senadores ruralistas não é tão evidente. Ao contrário do que aconteceu nos países europeus, a queda de representantes da elite rural não parece estar diretamente relacionada aos processos de industrialização e de urbanização, ao menos no que diz respeito ao Senado. Pelo contrário, a redução do número de empresários rurais durante o Império, e boa parte da Primeira República, dá-se no momento em que a agricultura, especialmente o setor cafeeiro, responde pela base da economia nacional. Quando o processo de industrialização ganha impulso nas décadas de 1940 e 1950, a elite rural retoma o seu crescimento no Senado. Isso fica ainda mais evidente na segunda metade dos anos de 1950, quando a indústria se torna o carro chefe da economia nacional.

No que diz respeito ao processo de urbanização, aconteceu situação semelhante. $\mathrm{O}$ aumento da população urbana não implicou uma redução dos senadores proprietários rurais. O Brasil foi um dos países que mais se urbanizaram durante o século passado, 


\section{Gráfico 7 \\ Outros}

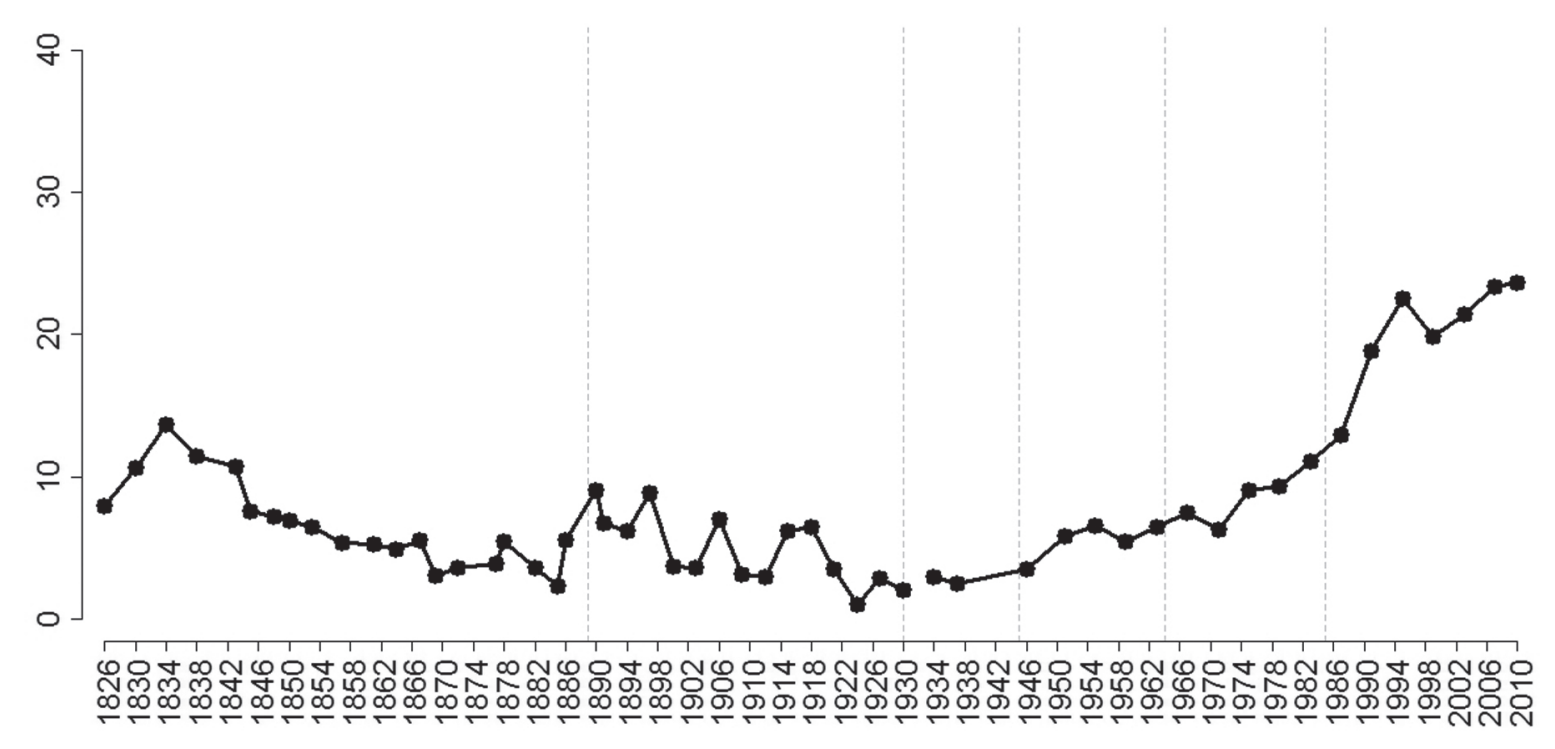

saindo de uma população rural de aproximadamente 85\% em 1920 para algo em torno de 32\% em 1980. No mesmo período, o percentual de empresários rurais no Senado saiu de $2 \%$ para $10 \%$ da Casa. Movimento contrário, portanto, ao que era de se esperar. No longo prazo, porém, houve uma redução do número de senadores nessa categoria profissional.

Uma possível explicação para tais paradoxos aumento da urbanização e da industrialização e pequeno aumento da proporção de empresários rurais pode estar relacionada com o fato de os estados terem representação igual no Senado. Os processos de urbanização e de industrialização, principalmente, estiveram concentrados em alguns estados e regiōes. A região Sudeste é a mais urbana, possui $42,1 \%$ da população do país e responde por mais da metade da sua produção industrial, mas conta com apenas $15 \%$ dos senadores. O estado do Rio de Janeiro tem pouco mais de 3\% da sua população vivendo na zona rural, mas conta com o mesmo número de representantes no Senado que tem o estado do Maranhão, cuja população rural gira ao redor de 40\% (IBGE, 2011). A desproporcionalidade de representação, portanto, pode distorcer uma análise envolvendo todo o país. Também por isso, faz sentido uma análise que considere a distribuição profissional dos senadores pelos estados, conforme fizemos mais adiante, na quinta seção.

\section{Outros}

A categoria "outros" abrange todas as profissões/ ocupações não contempladas anteriormente, tais como: administradores, economistas, sociólogos, arquitetos, assistentes sociais, escritores, trabalhadores manuais, sacerdotes, psicólogos etc. O Gráfico 7 mostra a sua evolução sob uma perspectiva histórica.

A categoria saiu de uma média $6,2 \%$ das cadeiras durante o Império para 5,1\% na Primeira República e 2,4\% no Estado Novo, até chegar a mais de 20\% na Nova República. A curva evolutiva apresenta dois picos mais evidentes. $\mathrm{O}$ primeiro deve-se à intensa participação política dos sacerdotes durante a Regência. ${ }^{10}$ Ao analisar a Câmara dos Deputados, Souza (2008) verificou que $22,5 \%$ dos seus membros na primeira legislatura eram padres; na segunda, na terceira e na quarta legislaturas, chegaram a 22\%, 24\% e $16 \%$, respectivamente. A partir daí, sua presença na 
Casa tornou-se cada vez menos significativa. Fato similar pôde ser constatado no Senado, para onde treze padres foram designados entre 1826 e 1841 . Durante todo o Segundo Reinado, somente quatro sacerdotes conseguiram ascender a tão alto cargo político.

Diversas explicações podem ser dadas para essa presença considerável de elementos da Igreja nos primeiros anos da independência do país. A primeira decorre do vazio de autoridade da administração portuguesa durante o período colonial; como as autoridades religiosas eram as mais presentes, acabaram ocupando esse espaço. Outra explicação deve-se ao alto nível educacional dos padres, que discrepava fortemente da massa de analfabetos que existia no país. Vale mencionar a ampla participação dos párocos na organização e nas decisões ligadas ao processo eleitoral, inclusive na designação de quem estaria apto para votar. Não se pode esquecer também a influência e a liderança pessoal do padre Antônio Feijó, que foi ministro da Justiça (1831-1832) e regente (1835-1837).

O segundo pico começa a se formar no final da ditadura militar e atinge o seu auge nas últimas legislaturas da Nova República. Esse aumento reflete a diversificação da sociedade e da sua representação política, que passou a incorporar outros grupos sociais, como as camadas médias (Codato, 2008) e os trabalhadores, ${ }^{11}$ representados principalmente por meio dos partidos de esquerda (Marcelino et al., 2010; Rodrigues, 2002). Ele expressa também o aumento da preocupação com a eficiência e a modernização do Estado, a partir da presença de administradores e economistas, que aumentaram o seu espaço na Casa de 0,4\% na República de 1946, para $1,7 \%$ no regime autoritário, passando para $8,3 \%$ na Nova República. ${ }^{12}$ De acordo com Loureiro (1997), em um contexto democrático, espera-se que os economistas percam poder como agentes burocráticos, ficando sob o controle de políticos eleitos. Não obstante, nossos dados (e também os de Santos, 2000) mostram que eles aumentaram a sua participação como representantes eleitos.

Tendências semelhantes foram identificadas em diversos países europeus. Na Alemanha, entre os anos de 1960 e 1980, os cientistas sociais e economistas aumentaram a sua participação para $40 \%$ das cadeiras e os cientistas naturais passaram a ocu- par quase 30\% delas (Wessels, 1997). Pilotti et al. (2010) também observaram um aumento crescente de economistas no parlamento suíço após os anos de 1950 e de cientistas sociais em anos mais recentes. Na Croácia, entre 1992 e 2003, os formados na área de humanidades e ciências sociais ocuparam aproximadamente $30 \%$ das cadeiras nesse período (Ilišin, 2007). Na opinião de Rodrigues (2002), essa elevação do nível de escolaridade dos parlamentares e do seu recrutamento majoritariamente em segmentos da classe média estaria levando a uma homogeneização dos parlamentos em países europeus.

\section{O impacto das mudanças institucionais}

No principal estudo já publicado sobre as câmaras altas, Tsebelis e Money (1997) alertam para o seu caráter protean, isto é, sua capacidade de adaptação a diversos contextos e ambientes. Segundo os dois autores, tais casas legislativas estão muito mais propensas a sofrerem mudanças do que as suas congêneres câmaras baixas. Estas variam desde pequenas alteraçôes regimentais ou constitucionais até a sua completa extinção. Essa percepção confirma-se na história do Brasil: o Senado sofreu muito mais alterações do que a Câmara dos Deputados. Nesta seção, analisamos duas delas com mais profundidade, dadas as relaçôes que podem ter com o fenômeno que estamos analisando.

A primeira alteração foi realizada por meio da Constituição de 1891, que implementou a república e o federalismo no país. Com ela, a representação dos senadores passou de uma distribuição proporcional à população para uma distribuição igualitária entre os estados membros, a exemplo do modelo norte-americano, que lhe serviu de inspiração. A mudança não foi pequena: o estado de Minas Gerais, por exemplo, saiu de quinze senadores para apenas três; já o estado de Goiás contava com apenas um senador, aumentando para três a partir da proclamação da República. Se as províncias (posteriormente, estados) diferiam entre si e se essa diferença implicava diferença de representação no Legislativo, é de se esperar que tais transformações tenham gerado um impacto sobre a distribuição das profissões no Legislativo. 
Afinal, "o Senado constituía-se do que havia de mais representativo nas províncias, ou seja, de uma elite socioeconômica, política e cultural" (Leite, 1978, p. 218). Ainda que a fidelidade ao imperador fosse um aspecto crucial na escolha dos senadores, ele decidia a partir de uma lista tríplice elaborada nas províncias. Nesse sentido, as características e os interesses locais pareciam ser também considerados. No Rio Grande do Sul, por exemplo, foram escolhidos como senadores o Marechal Osório, o Visconde de Pelotas e o Duque de Caxias, os três com importantes participações nos conflitos bélicos contra a Argentina, o Uruguai e o Paraguai.

Os Gráficos 8, 9 e 10 testam essa hipótese. Os valores estão dispostos em termos percentuais, por estado, separados nos dois períodos históricos que estão sendo comparados: Império e República. No intuito de preservar o leitor de um excesso de informação, limitamos a análise às três profissões mais expressivas para os nossos propósitos.

Os gráficos confirmam que a mudança de regra de seleção dos senadores alterou substancialmente a distribuição regional das profissões: no período republicano, ela é bem mais igualitária do que no período monárquico, no qual houve um predomínio de três ou quatro províncias. Com poucas exceções, há um razoável equilíbrio entre as profissões

\section{Gráfico 9}

\section{Empresários Rurais}

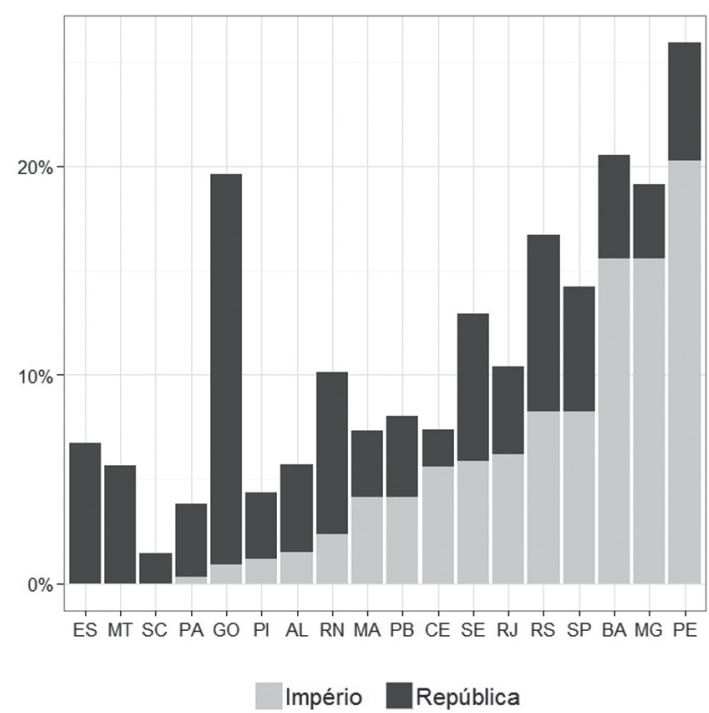

nos estados nesse segundo intervalo histórico. Por um lado, esses resultados sugerem que a relação entre a distribuição das profissões não está relacionada com a distribuição estadual dos senadores durante o período republicano. Por outro, mostra um quadro diferente durante o Império. Nesse último, percebe-se uma clara preponderância das províncias/
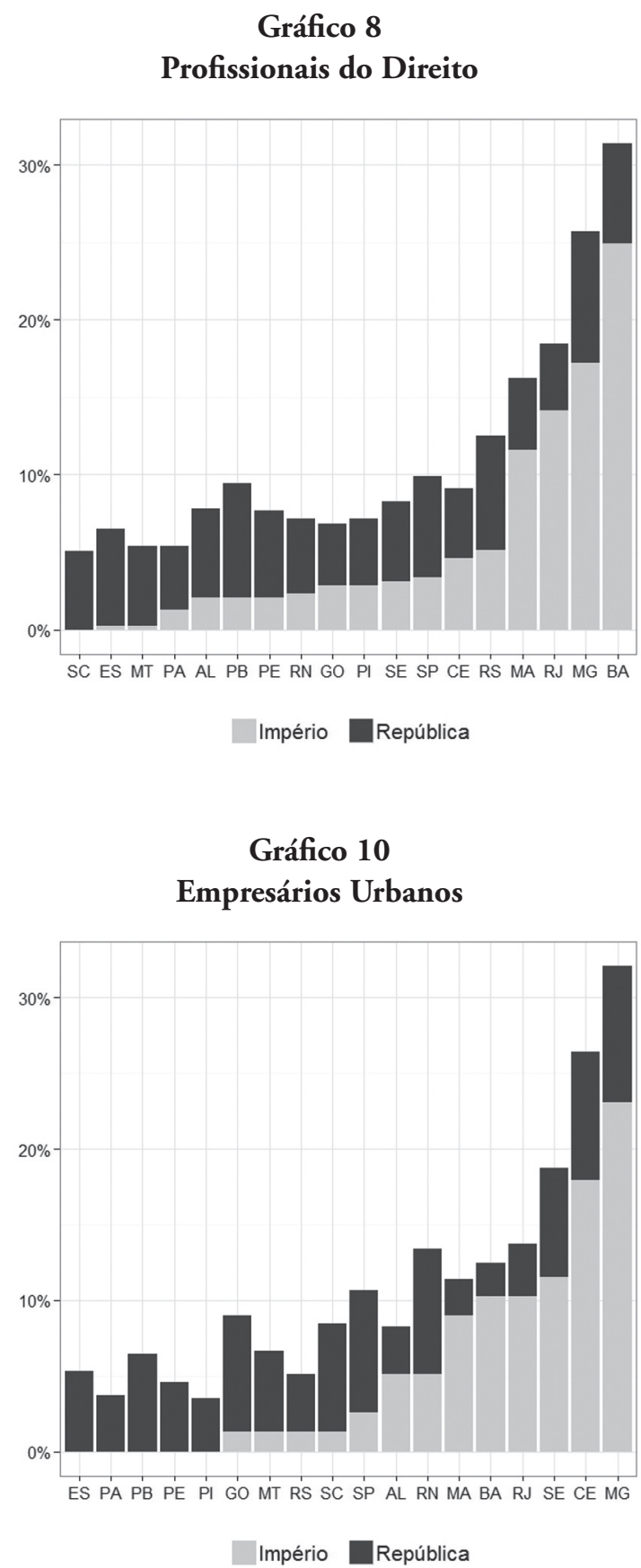
estados mais populosos e mais importantes à época: Bahia, Minas Gerais e Rio de Janeiro. A diferença entre estados, portanto, parece ser mera consequência da configuração institucional que estabelecia números diferentes de senadores entre eles. Não se pode dizer, no entanto, que essa seja obra do acaso. Pelo contrário, supostamente ela envolvia interesses políticos, inclusive no que diz respeito às profissões e à representação de interesse das elites.

Uma exceção ao padrão observado deve-se aos estados/províncias com forte produção agrícola/ pecuária: especificamente, Pernambuco no Império e Goiás na República, que apresentaram uma proporção maior de empresários rurais, a despeito de sua pequena proporção na população total do país. Embora esses dados não representem qualquer evidência de que o Senado seja uma "casa da agricultura" - conforme Duverger apontou para o Senado francês (apud Lijphart, 1999, p. 197), eles sugerem que os interesses agrícolas no Senado estão organizados em termos regionais. ${ }^{13}$

A segunda mudança institucional - na verdade, uma série delas - diz respeito à criação de novos estados, a saber: Acre (1962), Mato Grosso do Sul (1977), Rondônia (1981), Tocantins (1988), Roraima (1988), Amapá (1988). Consideramos também o Distrito Federal, que passou a eleger os seus senadores a partir de 1987. No Gráfico 11, podemos ver o impacto que eles tiveram sobre a distribuição da profissão de senadores.

Conforme se observa, os novos estados apresentaram uma concentração razoavelmente maior de empresários rurais. Apesar de serem responsáveis por apenas $16 \%$ dos estados, eles contaram com mais de $30 \%$ daquela categoria profissional. Isso foi consequência, principalmente, do grande percentual de empresários rurais dos estados de Mato Grosso do Sul e de Tocantins, que se destacaram como as maiores fronteiras agropecuárias do país em anos recentes.

\section{Consideraçôes finais}

Chegamos a algumas conclusões importantes nessa pesquisa. Identificamos um Senado com pouca variação no curto prazo em termos de distribuição profissional de seus membros, reforçando a ideia de uma casa legislativa onde prevalece a estabilidade e a manutenção do status quo. No longo prazo, verificamos que algumas profissões apresentaram pouca variação; é o caso dos professores e dos profissionais da saúde, por exemplo. Outras variaram bastante ao longo de quase dois séculos de existência, tais como: advogados, magistrados, militares e servidores públicos.

A análise por períodos históricos identificou o Império como mais estável do que a Primeira República. Além do fato de os senadores serem escolhidos pelo imperador e de eles terem mandato permanente, sugerimos que a homogeneidade ideológica e a distribuição de poder entre membros da elite seriam fatores adicionais para explicar esse fenômeno. Mostrou também alteraçôes importantes

\section{Gráfico 11}

\section{Distribuição de Profissóes entre Estados Novos e Antigos}

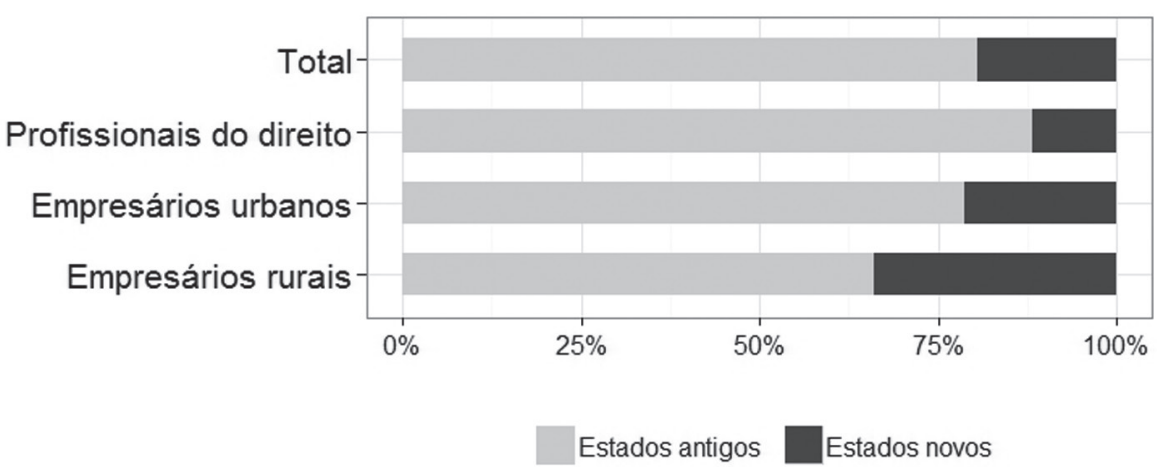


entre os dois períodos, especialmente nos casos dos servidores públicos, militares e empresários rurais. Revelou ainda que o Senado se tornou mais complexo nos últimos anos, ao menos no que diz respeito à variedade de categorias profissionais.

Verificamos que boa parte das explicaçóes para a distribuição das profissões dos senadores decorre da forma como são distribuídos regionalmente. A representação desigual das províncias ajuda a justificar a diferença durante o período imperial. A mudança realizada pela Constituição de 1891 - que mudou a regra de representação no Senado, de proporcional para a de número fixo de senadores por estado - explica boa parte das mudanças mais acentuadas do regime monárquico para o republicano. Observamos ainda que a criação de novos estados nas últimas décadas também teve algum impacto sobre tal distribuição, especialmente por causa da sobre-representação do setor rural nessas regiões.

Em parte, nossos achados contrariam a ideia clássica de que à medida que as sociedades se tornam mais diferenciadas e complexas passa a ser necessário maior grau de homogeneidade, de coesão e de consenso entre suas elites. Acreditamos sim que uma maior diferenciação entre as profissões e as ocupações interfere na forma de interação entre tais elites e, consequentemente, no nível de estabilidade política. No entanto, é preciso considerar que elas não são a única forma pela qual os parlamentares agregam valores. Eles podem convergir ou divergir em função de várias outras características: por afinidade ideológica, origem territorial comum, vínculos familiares, religião, aliança com o governo nacional ou estadual, regras institucionais ou até mesmo por conta da interação pessoal. Estudos futuros poderão incluir tais atributos na avaliação. Particularmente importante são as informações sobre suas respectivas filiações partidárias, que têm-se mostrado uma referência fundamental na atuação dos legisladores brasileiros.

Não foi possível, no âmbito dessa pesquisa, avaliar a relação entre a distribuição ocupacional dos senadores e seus efeitos sobre os resultados políticos, sobre suas atitudes e sobre o seu comportamento legislativo. Não sabemos, por exemplo, se ela faz diferença para as votaçóes nominais realizadas na Casa. Essa é uma agenda de pesquisa que merece ser apoiada. As análises sobre o Legislativo brasileiro, a exemplo do que acontece nos Estados Unidos, estão excessivamente baseadas nos seus aspectos institucionais. Sem desmerecer a importância das instituiçôes, acreditamos que o perfil individual dos legisladores pode nos ajudar a entender melhor o seu funcionamento, especialmente no caso do Senado, uma casa menos estruturada, mais fluida, com relaçôes pessoais mais frequentes, menos hierarquizadas e com regras de funcionamento menos estritas.

\section{Notas}

1 Os conceitos de ocupação e profissão não são exatamente sinônimos. $\mathrm{O}$ primeiro diz respeito às diversas atividades do mundo do trabalho. $\mathrm{O}$ segundo costuma ser entendido como um tipo especial de ocupação; em geral, envolve o domínio de certo tipo de conhecimento e de especialização, proporciona relativa autonomia e conta com grau maior de institucionalização. Essas diferenças não são importantes para o nosso propósito, motivo pelo qual usaremos os dois indistintamente.

2 O Conselho de Estado era o órgão ao qual o imperador supostamente deveria ouvir antes de exercer o Poder Moderador.

3 A palavra vem do Deus grego "Proteus", homem velho e profético que morava no mar, mudava constantemente de forma e tinha a capacidade de prever o futuro.

4 A medida tinha o objetivo de garantir ao governo militar maioria na câmara alta, evitando a repetição da derrota que havia sofrido na maioria dos estados na eleição de 1974

5 A única exceção ficou por conta da 36a Legislatura (1933 a 1934), cujos dados não foram disponibilizados pelo Senado.

6 Vale lembrar a mudança implementada pela constituição republicana de 1891 , que retirou a vitaliciedade do mandato dos senadores, o qual passou a ser renovado na proporção de um terço a cada três anos.

7 Entre as principais diferenças, podem ser destacadas as seguintes: o Senado brasileiro não foi criado sob a instauração de um regime federativo, que só apareceu com a República em 1891; as assembleias provinciais escolhiam os senadores (a exemplo do modelo norte-americano) em uma lista tríplice, mas a decisão final era do imperador; os senadores do Império tinham mandato vitalício. 
8 Outras formaçóes entre os que compunham o Ministério imperial, com suas respectivas frequências: $7 \%$ ciências exatas; $16,5 \%$ - militares; $3,5 \%$ - Medicina; $0,5 \%$ - religiosos.

9 O ligeiro declínio que os dois autores identificaram na Câmara dos Deputados durante o regime autoritário que se iniciou em 1964 não aconteceu no Senado.

10 Período compreendido no decênio de 1831 a 1840, entre a abdicação de Dom Pedro I e o chamado "Golpe da Maioridade". Por meio desse último, Dom Pedro II teve a maioridade proclamada pelo Senado aos 14 anos de idade, com o objetivo de por fim às revoltas que estavam acontecendo no país, ameaçando a sua integridade.

11 Não obstante, os trabalhadores continuam contando com participação bem menor do que o seu peso na população. Segundo Perissinotto e Miríade (2009), os assalariados urbanos ocupavam apenas $1,8 \%$ das cadeiras da Câmara dos Deputados em 2006. Assemelham-se, nesse particular, ao que aconteceu nos Estados Unidos, onde ocupavam apenas 4\% das cadeiras, apesar de representarem $26 \%$ da população (Herrnson, 1997).

12 Aumento semelhante foi identificado por Santos (2000) na Câmara dos Deputados, onde os economistas ocupavam apenas 1,6\% entre 1946 e 1967, passando para 7\% com a redemocratização.

13 Não obstante, essas evidências não excluem outras províncias com forte produção agrícola durante o Império, como Rio de Janeiro, Minas Gerais e São Paulo, que possuíam mais escravos do que todas as outras juntas (Leite, 1978). As duas primeiras, especialmente, contaram também com grande número de empresários rurais.

\section{BIBLIOGRAFIA}

BEST, H. \& COTTA, M. (2000), Parliamentary representatives in Europe, 1848-2000: legislative recruitment and careers in eleven European countries. Nova York, Oxford University Press.

BEST, H. \& GAXIE, D. (2000), "Detours to modernity: long-term trends of parliamentary recruitment in Republican France 1848-1999”. Parliamentary representatives in Europe 18482000: Legislative recruitment and careers in eleven european countries. Oxford, Oxford University Press, pp. 88-137.
BOLOGNESI, B. \& PERISSINOTTO, R. (2011), "Electoral success and political institutionalization in the federal deputy elections in Brazil (1998, 2002 and 2006)". Brazilian Political Science Review, 4 (1): 10-33.

BRAGA, M.; VEIGA, L. \& MIRÍADE, A. (2009), "Recrutamento e perfil dos candidatos e dos eleitos à Câmara dos Deputados nas eleições de 2006”. Revista Brasileira de Ciências Sociais, 24 (70): 123-142.

CARVALHO, J. (2003), A construção da ordem, teatro de sombras. Rio de Janeiro, Civilização Brasileira.

CODATO, A. (2008), "A formação do campo político profissional no Brasil: uma hipótese a partir do caso de São Paulo". Revista de Sociologia e Política, 16 (30): 89-105.

COELHO, E. (1999), As profissões imperiais: medicina, engenharia e advocacia no Rio de Janeiro, 1822-1930. Rio de Janeiro, Record.

COTTA, M. \& BEST, H. (2000), "Between professionalization and democratization: a synoptic view on the making of the European representative", in H. Best e M. Cotta (eds.), Parliamentary representatives in Europe - 1848-2000), Oxford, Oxford University Press, pp. 493-526.

CULIC, I. (2006), "From amateur revolutionaries to professional politicians: the Transformation of the romanian political elite, 1990-2004". International Journal of Sociology, 36 (1): 69-92.

DINIZ, E. \& BOSCHI, R. (2000), "Globalização, herança corporativa e a representação dos interesses empresariais: novas configurações no cenário pós-reformas", in R. Boschi, E. Dizin e F. Santos (eds.), Elites econômicas e politicas no Brasil contemporâneo, São Paulo, Fundação Konrad Adenauer, pp. 15-88.

DOGAN, M. (2003), "Is there a ruling class in France?”. Comparative Sociology, 2 (1): 17-89.

FAORO, R. (1958), "Os Donos do Poder: Formação do Patronato Político Brasileiro", Rio de Janeiro/Porto Alegre/São Paulo, Editora Globo. GAXIE, D. \& GODMER, L. (2007), "Cultural capital and political selection: educational backgrounds of parliamentarians", in M. Cotta $\&$ H. Best (eds.), Democratic representation in Europe: diversity, change, and convergence, Nova York, Oxford University Press, pp. 106-135. 
HAMILTON, A.; MADISON, J. \& JAY, J. (2005), The federalist. Indianapolis, Hackett.

HEINZ, F. (2006), Por outra história das elites. Rio de Janeiro, FGV.

HERRNSON, P. (1997), "United States", in P. Norris (ed.), Passages to power: Legislative recruitment in advanced democracies, Nova York, Cambridge University Press, pp. 187-208.

IBGE (2011). "Censo demográfico brasileiro 2010”. Disponível em <www.ibge.gov.br>, acessado em 29/11/2011.

ILIŠIN, V. (2007), "The social structure of the Croatian parliament in five mandates". Politika Misao, XLIV (5): 45-70.

LAREAU, A. \& CONLEY, D. (2008), Social class: How does it work? Nova York, Russell Sage.

LEITE, B. (1978), O Senado nos anos finais do Império: 1870-1889. Brasília, Editora da Universidade de Brasília.

LEMOS, L. \& RANINCHESKI, S. (2002), "O perfil sociopolítico dos senadores brasileiros". Revista Senatus, 1 (1): 33-39.

LIJPHART, A. (1999), Patterns of democracy: government forms and performance in thirty-six countries. New Haven, Yale University, 1999.

LOUREIRO, M. (1997), Os Economistas no governo: gestâo econômica e democracia. Rio de Janeiro, FGV.

LOVE, J. \& BARICKMAN, B. (2006), "Elites regionais", in F. Heinz (ed.), Por outra história das elites, Rio de Janeiro, FGV, pp. 77-98.

MAGONE, J. (2000), "Political recruitment and elite transformation in modern Portugal 18701999: the late arrival of mass representation", in H. Best e M. Cotta (eds.), Parliamentary representatives in Europe, 1848-2000: Legislative recruitment and careers in eleven European countries, Oxford, Oxford University Press, pp. 341-370.

MARCELINO, D.; BRAGA, S. \& COSTA, L. D. (2010), "Parlamentares na Constituinte de 1987/88: uma contribuição à solução do 'enigma do Centrão'”. Revista Politica Hoje, 18 (2): 239-279.

MATTES, R. \& MOZAFFAR, S. (2011), Education, legislators and legislatures in Africa. Trabalho apresentado no Centre for Higher Education Transformation.
MATTHEWS, D. (1984), "Legislative recruitment and legislative careers". Legislative Studies Quarterly, 9 (4): 547-585.

(1985), "Legislators and constituencies", in G. Loewenberg, S. Patterson e M. Jewell (eds.), Handbook of legislative research. Cambridge, Harvard University Press.

MELLORS, C. (1978), British MP: a socio-economic study of the House of Commons. Farnborough, Saxon House.

NEIVA, P. (2006), "Determinantes da existência e dos poderes das câmaras altas: federalismo ou presidencialismo?". Dados: Revista de Ciências Sociais, 49 (2): 269-299.

. (2011). "Coesão e disciplina partidária no Senado federal". Dados: Revista de Ciências Sociais, 54 (1): 289-318.

NEIVA, P. \& IZUMI, M. (2012), “Os 'doutores' da federação: formação acadêmica dos senadores brasileiros e variáveis associadas". Revista de Sociologia e Política, 19 (39): 171-192.

PARETO, V. (1966), "As elites e o uso da força na sociedade", in Amaury de Souza (org.), Sociologia Política, Rio de Janeiro, Zahar.

PATTERSON, S. (1968), "Comparative Legislative behavior: a review essay". Midwest Journal of Political Science, 12 (4): 599-616.

PEDERSEN, M. N. (2000), "The incremental transformation of the Danish legislative elite: the party system as prime mover", in $\mathrm{H}$. Best e M. Cotta (eds.), Parliamentary representatives in Europe, 1848-2000: Legislative recruitment and careers in eleven European countries, Oxford, Oxford University Press, pp. 29-49.

PERISSINOTTO, R. \& MIRÍADE, A. (2009), "Caminhos para o parlamento: candidatos e eleitos nas eleições para deputado federal em 2006". Dados: Revista de Ciências Sociais, 52 (2): 301-333.

PILOTTI, A.; MACH, A. \& MAZZOLENI, O. (2010), "Les parlementaires suisses entre démocratisation et professionnalisation, 19102000". Swiss Political Science Review, 16 (2): 211-245.

PINHO, Wanderley. (1937). O Barão de Cotegipe e o seu tempo. São Paulo, Companhia Editora Nacional. 
RODRIGUES, L. (2002), Partidos, ideologia e composição social: um estudo das bancadas partidárias na Câmara dos Deputados. São Paulo, Edusp.

RUOSTETSAARI, I. (2000), From political amateur to professional politician and expert representative: parliamentary recruitment in Finland since 1863. Oxford, Oxford University Press.

RUSH, M. \& CROMWELL, V. (2000), “Continuity and change: Legislative recruitment in the United Kingdom 1868-1999", in H. Best e M. Cotta (eds.), Parliamentary representatives in Europe, 1848-2000: Legislative recruitment and careers in eleven European countries, Oxford, Oxford University Press, pp. 463-492.

SANTANA, L. (2008), "Perfil, trajetórias e ambição política dos legisladores na construção de suas carreiras: Argentina, Brasil, Chile e Uruguai". Teoria e Sociedade, 16 (2): 130-155.

SANTOS, F. (2000), Deputados federais e instituições legislativas no Brasil: 1946-99", in F. Santos, R. Boschi e E. Diniz (orgs.), Elites politicas e econômicas no Brasil contemporâneo, São Paulo, Konrad Adenauer Stiftung.

SAYARI, S. \& HASANOV, A. (2008), “The 2007 elections and parliamentary elites in Turkey: the emergence of a new political class?". Turkish Studies, 9 (2): 345-361.

SCHULZ, J. (1994), O exército na politica: origens da intervenção militar, 1850-1894. São Paulo, Edusp.

SECKER, I. (2000), "Representatives of Dutch people: the smooth transformation of the parliamentary elite in a consociational democracy 1849-1998, in H. Best e M. Cotta (eds.), Parliamentary representatives in Europe, 1848-2000: Legislative recruitment and careers in eleven European countries, Oxford, Oxford University Press, pp. 270-309.

SELIGMAN, L. (1964), "Elite recruitment and political development". The Journal of Politics, 26 (3): 612-626.

SERNA, M. (2009), La composición de la élite politica uruguaya: circulación y reconversión en democracia. Trabalho apresentado no $33^{\circ}$ Encontro Anual da Anpocs.
SERNA, M. \& BOTTINELLI, E. (2009), La composición de la élite politica uruguaya: circulación y reconversión en democracia. Trabalho apresentado no Latin American Studies Association.

SILVEIRA, D. (2009), "Direito e política no Brasil Imperial: uma releitura do papel da magistratura na construção do Estado brasileiro". Ciências Sociais Aplicadas em Revista, 9: 1-22.

SOUZA, F. (2008), "Religião e política no primeiro reinado e regências: a atuação dos padres-políticos no contexto de formação do Estado Imperial Brasileiro". Almanack Braziliense, 8: 127-137.

TSEBELIS, G. \& MONEY, J. (1997), Bicameralism. Cambridge, Cambridge University Press.

URIARTE, E. (1997), "El análisis de las elites políticas en las democracias". Revista de Estudios Políticos, 97: 249-275.

VENÂNCIO FILHO, A. (1982), Das arcadas ao bacharelismo (150 anos de ensino jurídico no Brasil). São Paulo, Perspectiva.

VIANNA, Luiz W. et al. (1997), Corpo e alma da magistratura brasileira. Rio de Janeiro, Revan/Iuperj.

WEBER, M. (1999). "Ciência e política: duas vocações”. Tradução de Leônidas Hegenberg e Octany Silveira da Mota. São Paulo, Cultrix.

WENCES, R. (1969), "Electoral participation and the occupational composition of cabinets and parliaments". The American Journal of Sociology, 75 (2): 181-192.

WESSELS, B. (1997), "Germany", in P. Norris (ed.), Passages to power: Legislative recruitment in advanced democracies, Cambridge, Cambridge University Press, pp. 76-97. 


\section{Apêndice 1}
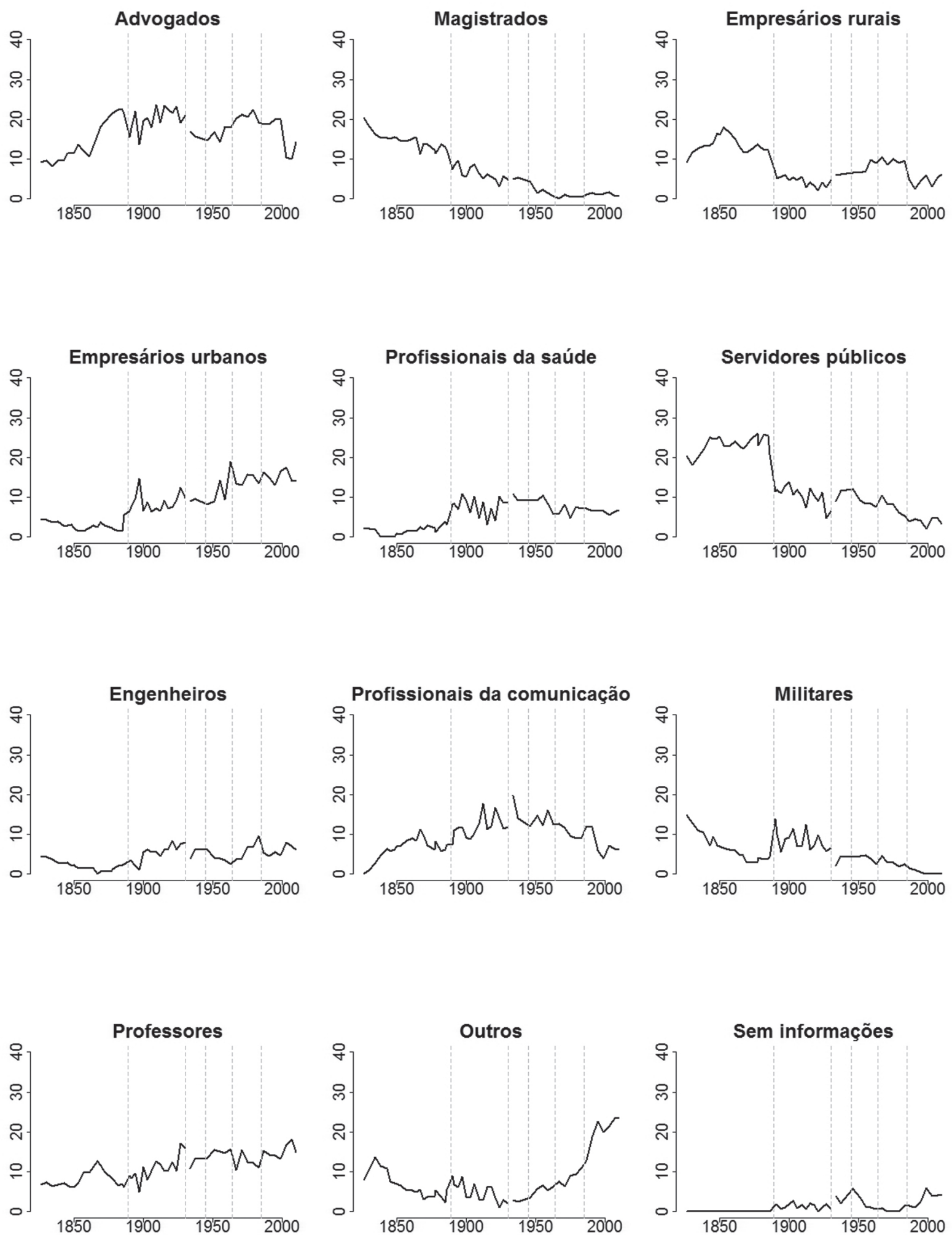


\section{Apêndice 2}

Tabela 2

Categorias Profissionais/Ocupacionais dos Senadores Brasileiros.

Proporção, por Período Histórico - 1822-2010

\begin{tabular}{|c|c|c|c|c|c|c|}
\hline & $\begin{array}{l}\text { Império } \\
(1822- \\
1889)\end{array}$ & $\begin{array}{l}\text { Repúb. } \\
\text { Velha } \\
(1889- \\
1930)\end{array}$ & $\begin{array}{l}\text { Era Vargas } \\
(1930- \\
1945)\end{array}$ & $\begin{array}{l}\text { Repúb. } \\
\text { Populista } \\
\text { (1945- } \\
1964)\end{array}$ & $\begin{array}{l}\text { Ditadura } \\
\text { Militar } \\
(1964- \\
1985)\end{array}$ & $\begin{array}{l}\text { Nova } \\
\text { República } \\
\text { (1985- } \\
\text { Hoje) }\end{array}$ \\
\hline Advogados & 15,2 & 20 & 17,6 & 16,3 & 20,7 & 16,4 \\
\hline Empresários Rurais & 13,4 & 4,4 & 5,7 & 7,7 & 9,4 & 4,6 \\
\hline Empresários Urbanos & 2,8 & 8,4 & 9,5 & 12,2 & 14,3 & 15,1 \\
\hline Engenheiros & 1,9 & 5,1 & 6,3 & 3,9 & 6,4 & 5,7 \\
\hline Magistrados & 14,3 & 6,5 & 5,1 & 2 & 0,5 & 1,1 \\
\hline Militares & 6,2 & 8,7 & 4,6 & 3,9 & 2,8 & 0,5 \\
\hline Professores & 8,2 & 10,5 & 13,5 & 14,9 & 12,4 & 15,2 \\
\hline Profissionais da Comunicação & 6,7 & 12 & 14,5 & 13,5 & 10,2 & 8 \\
\hline Profissionais da Saúde & 1,7 & 7,5 & 9,3 & 8,5 & 6,8 & 6,5 \\
\hline Servidores Públicos & 23,3 & 10,5 & 9,5 & 9,1 & 7,4 & 3,9 \\
\hline Outros & 6,2 & 5,1 & 2,4 & 5,6 & 8,7 & 20 \\
\hline Sem informação & 0 & 1,3 & 2 & 2,4 & 0,4 & 3,1 \\
\hline $\mathrm{N}$ & 2531 & 1672 & 495 & 1267 & 974 & 1207 \\
\hline
\end{tabular}

Fonte: Banco de dados montado pelos autores a partir de informações contidas na página do Senado na internet. 


\section{PERFIL PROFISSIONAL E DISTRIBUIÇÃO REGIONAL DOS SENADORES BRASILEIROS EM DOIS SÉCULOS DE HISTÓRIA}

\section{Pedro Neiva e \\ Maurício Izumi}

Palavras-chave: Elites; Carreira política; Perfil de senadores; Legislativo; Profissōes.

Esse estudo mapeia o perfil profissional/ ocupacional dos senadores brasileiros de 1826 a 2010, procurando avaliar eventuais relações entre a sua composição profissional com os respectivos períodos históricos do país. Identificamos pouca variação no curto prazo, o que reforça a percepção do Senado como uma Casa legislativa onde prevalece a estabilidade e a manutenção do status quo. No entanto, observamos alteraçóes importantes no longo prazo: de um predomínio de servidores públicos, magistrados e proprietários rurais durante o Império, o Senado tornou-se uma Casa bem mais diversificada em décadas recentes, com pouca predominância de grupos específicos. Verificamos também que as regras de seleção dos senadores provocaram algum impacto sobre a distribuição de profissōes, com destaque para dois tipos de alteração constitucional: a transformação da representação proporcional em igualitária, que estabeleceu o número fixo de dois senadores por estado, empreendida pela Constituição de 1891; a criação de novos estados nas últimas décadas do século $\mathrm{XX}$, que provocou o aumento de representantes do setor rural.

\section{PROFESSIONAL PROFILE AND REGIONAL DISTRIBUTION OF BRAZILIAN SENATORS IN TWO CENTURIES OF HISTORY}

\section{Pedro Neiva and Maurício Izumi}

Keywords: Elites; Political career; Senators' profiles; Legislative; Professions.

The article examines the professional/ occupational profiles of Brazilian senators from 1826 to 2010 , intending to appraise contingent relations between the Senate's professional composition and the country's respective historical periods. Little variation was observed in the short run, reinforcing the perception of the Senate as a House where prevails stability and the maintenance of the status quo. In the long run, however, one can observe important changes: from the predominance of public servants, magistrates and landowners during the Empire, the Senate became a much more diversified House in recent decades, with little predominance of specific groups. The research also verified that the rules of selection of senators caused some impact over the distribution of professions, with emphasis on two types of constitutional change: the transformation of the representation from proportional to egalitarian, establishing a fixed number of two senators per state, undertook by the 1891 Constitution; and the creation of new states in the last decades of the twentieth century, what provoked an increase in the participation of representatives of the rural sector.

\section{PROFIL PROFESSIONNEL ET DISTRIBUTION RÉGIONALE DES SÉNATEURS BRÉSILIENS AU LONG DE DEUX SIĖCLES D'HISTOIRE}

\section{Pedro Neiva et Maurício Izumi}

Mots-clés: Élites; Carrière politique; Profil de sénateurs; Législatif; Professions.

Cette étude trace le profil professionnel et occupationnel des sénateurs brésiliens entre 1826 et 2010 , en cherchant d'évaluer d'éventuelles relations entre leur composition professionnelle et les respectives périodes historiques du Brésil. Nous n'avons identifié qu'une moindre variation à court terme, ce qui renforce la perception du Sénat en tant que Maison législative dans laquelle prévalent la stabilité et la manutention du statu quo. Néanmoins, nous observons des changements importants à long terme: d'une majorité de fonctionnaires, de magistrats et de propriétaires ruraux pendant l'Empire, le Sénat est devenu une Maison davantage diversifiée au cours de ces dernières décennies, avec peu de prédominance de groupes spécifiques. Nous avons également vérifié que les règles de sélection des sénateurs ont provoqué un certain impact sur la distribution des professions, en mettant en avant deux genres de changement constitutionnel: la transformation, entreprise par la Constitution de 1891, de la représentation proportionnelle en égalitaire, ce qui a permis de rétablir le nombre fixe de deux sénateurs par État, et la création de nouveaux États au cours des dernières décennies du $\mathrm{XX}^{\mathrm{e}}$ siècle, ce qui a provoqué l'augmentation de représentants du milieu rural. 